\title{
Metabolic Syndrome, Chronic Kidney Disease, and Cardiovascular Disease: A Dynamic and Life-Threatening Triad
}

\author{
Mário Raimundo and José António Lopes \\ Department of Nephrology and Renal Transplantation, Centro Hospitalar Lisboa Norte, EPE, Hospital de Santa Maria, \\ Avenida Professor Egas Moniz, 1649-035 Lisboa, Portugal \\ Correspondence should be addressed to José António Lopes, jalopes93@hotmail.com
}

Received 7 October 2010; Revised 6 December 2010; Accepted 24 December 2010

Academic Editor: Ken Ichi Aihara

Copyright ( 2011 M. Raimundo and J. A. Lopes. This is an open access article distributed under the Creative Commons Attribution License, which permits unrestricted use, distribution, and reproduction in any medium, provided the original work is properly cited.

The metabolic syndrome (MS) and chronic kidney disease (CKD) have both become global public health problems, with increasing social and economic impact due to their high prevalence and remarkable impact on morbidity and mortality. The causality between MS and CKD, and its clinical implications, still does remain not completely understood. Moreover, prophylactic and therapeutic interventions do need to be properly investigated in this field. Herein, we critically review the existing clinical evidence that associates MS with renal disease and cardiovascular disease, as well as the associated pathophysiologic mechanisms and actual treatment options.

\section{Introduction}

During the last decades, we have witnessed a global epidemic of obesity [1]. A sedentary lifestyle and an atherogenic diet, along with genetic predisposition, are probably the driving forces of this problem. According to the last National Health and Nutrition Examination Survey (NHANES), more than one third of adult Americans are obese. The prevalence in children and adolescents is also rising at an alarmingly rate [2].

Obesity, particularly abdominal obesity, is associated with resistance to the effects of insulin on peripheral glucose and fatty acid utilization. The resulting hiperinsulinemia and hyperglycemia, as the release of adipocyte cytokines, have been shown to induce vascular endothelial dysfunction, an abnormal lipid profile, hypertension, and vascular inflammation, all of which are atherogenic [3-6]. The clustering of metabolic cardiovascular risk factors, under a common pathogenic process (insulin resistance), was described for the first time in 1988 by Reaven [3], leading to the concept of Metabolic Syndrome (MS). Since then, multiple definitions have been made, all of them considering some combination of insulin resistance, dyslipidemia (hypertriglyceridemia, low
HDL cholesterol), elevated fasting serum glucose, abdominal obesity, and hypertension (Table 1) [7-11].

The MS affects over 20\% of adults in Western populations [12], and is becoming increasingly common [13-15], inclusively in adolescents [16]. However, the prevalence of MS varies widely according to geographic location, race, gender, and urbanization. Since it was first described, an overwhelming body of evidence associated the MS with subsequent development of type II diabetes mellitus and cardiovascular disease (CVD) [17-25]. Recently, the evidence associating MS with CVD has been synthesized in three meta-analyses that showed an increased risk for incident CVD (ranging from 53\% to 118\%) and all-cause mortality (ranging from 27\% to 60\%) in subjects with MS [23-25]. This increased risk appears related to the risk factor clustering, rather than to obesity alone, as normal weight people from the Framingham population meeting the criteria for MS had a threefold increased risk for CVD, while obese individuals without MS did not have a significantly increased risk [26].

Additionally, especially in the last decade, a number of other obesity-related disorders have been associated with the MS, including: fatty liver disease, polycystic ovary syndrome, 
TABLE 1: Current definitions of the metabolic syndrome.

\begin{tabular}{|c|c|c|c|c|c|}
\hline Parameters & $\begin{array}{l}\text { NCEP ATP3 } \\
(2005)[9]\end{array}$ & $\begin{array}{l}\text { IDF } \\
(2005)[11] \\
\end{array}$ & $\begin{array}{l}\text { EGIR } \\
(1999)[8]\end{array}$ & $\begin{array}{l}\text { WHO } \\
(1999)[7]\end{array}$ & $\begin{array}{l}\text { NHLBI/AHA } \\
(2005)[10]\end{array}$ \\
\hline Required & & $\begin{array}{l}\text { Waist } \geq 94 \mathrm{~cm} \\
(\text { men }) \text { or } \\
\geq 80 \mathrm{~cm} \\
\text { (women) }^{(\mathrm{a})}\end{array}$ & $\begin{array}{l}\text { IR or fasting } \\
\text { hyperinsuline- } \\
\text { mia in top } \\
25 \%\end{array}$ & $\begin{array}{l}\text { IR in top } 25 \%^{(\mathrm{b})} ; \\
\text { glucose } \geq \\
110 \mathrm{mg} / \mathrm{dL} \\
(\geq 6.1 \mathrm{mmol} / \mathrm{L}) ; \\
2-\mathrm{hr} \text { glucose } \\
\geq 140 \mathrm{mg} / \mathrm{dL} \\
(\geq 7.8 \mathrm{mmol} / \mathrm{L})\end{array}$ & \\
\hline $\begin{array}{l}\text { No. of } \\
\text { abnormalities }\end{array}$ & $\geq 3$ of: & And $\geq 2$ of: & And $\geq 2$ of: & And $\geq 2$ of: & $\geq 3$ of: \\
\hline Obesity & $\begin{array}{l}\text { Waist } \geq 102 \mathrm{~cm}(\text { men }) \\
\text { or } \geq 88 \mathrm{~cm}(\text { women })^{(\mathrm{c})}\end{array}$ & & $\begin{array}{l}\text { Waist } \geq 94 \mathrm{~cm} \\
\text { (men) or } \\
\geq 80 \mathrm{~cm} \\
\text { (women) }\end{array}$ & $\begin{array}{l}\text { Waist } / \text { hip ratio } \\
>0.9 \text { (men) or } 0.85 \\
\text { (women) or BMI } \\
\geq 30 \mathrm{~kg} / \mathrm{m}^{2}\end{array}$ & $\begin{array}{l}\text { Waist } \geq 102 \mathrm{~cm} \text { (men) or } \\
\geq 88 \mathrm{~cm} \text { (women) }\end{array}$ \\
\hline Hypertension & $\begin{array}{l}\geq 130 / 85 \mathrm{~mm} \mathrm{Hg} \text { or } \\
\text { drug treatment }\end{array}$ & $\begin{array}{l}\geq 130 / 85 \mathrm{~mm} \mathrm{Hg} \\
\text { or drug } \\
\text { treatment }\end{array}$ & $\begin{array}{l}\geq 140 / 90 \mathrm{~mm} \mathrm{Hg} \\
\text { or drug } \\
\text { treatment }\end{array}$ & $\geq 140 / 90 \mathrm{~mm} \mathrm{Hg}$ & $\begin{array}{l}\geq 135 / 85 \mathrm{~mm} \mathrm{Hg} \text { or drug } \\
\text { treatment }\end{array}$ \\
\hline Glucose & $\begin{array}{l}\geq 100 \mathrm{mg} / \mathrm{dL} \\
(\geq 5.6 \mathrm{mmol} / \mathrm{L}) \text { or drug } \\
\text { treatment }\end{array}$ & $\begin{array}{l}\geq 100 \mathrm{mg} / \mathrm{dL} \\
(\geq 5.6 \mathrm{mmol} / \mathrm{L}) \\
\text { or diagnosed } \\
\text { diabetes }\end{array}$ & $\begin{array}{l}110-125 \mathrm{mg} / \mathrm{dL} \\
(6.1- \\
6.9 \mathrm{mmol} / \mathrm{L})\end{array}$ & & $\begin{array}{l}\geq 100 \mathrm{mg} / \mathrm{dL} \\
(\geq 5.6 \mathrm{mmol} / \mathrm{L}) \text { or drug } \\
\text { treatment }\end{array}$ \\
\hline $\begin{array}{l}\text { HDL } \\
\text { cholesterol }\end{array}$ & $\begin{array}{l}<40 \mathrm{mg} / \mathrm{dL} \\
(<1.0 \mathrm{mmol} / \mathrm{L})(\mathrm{men}) ; \\
<50 \mathrm{mg} / \mathrm{dL} \\
(<1.3 \mathrm{mmol} / \mathrm{L}) \\
\text { (women) or drug } \\
\text { treatment }\end{array}$ & $\begin{array}{l}<40 \mathrm{mg} / \mathrm{dL} \\
(<1.0 \mathrm{mmol} / \mathrm{L}) \\
(\mathrm{men}) ; \\
<50 \mathrm{mg} / \mathrm{dL} \\
(<1.3 \mathrm{mmol} / \mathrm{L}) \\
\text { (women) or } \\
\text { drug treatment }\end{array}$ & $\begin{array}{l}<40 \mathrm{mg} / \mathrm{dL} \\
(<1.0 \mathrm{mmol} / \mathrm{L})\end{array}$ & $\begin{array}{l}<35 \mathrm{mg} / \mathrm{dL} \\
(<0.9 \mathrm{mmol} / \mathrm{L}) \\
(\mathrm{men}) ;<40 \mathrm{mg} / \mathrm{dL} \\
(<1.0 \mathrm{mmol} / \mathrm{L}) \\
(\text { women })\end{array}$ & $\begin{array}{l}<40 \mathrm{mg} / \mathrm{dL} \\
(<1.0 \mathrm{mmol} / \mathrm{L})(\mathrm{men}) ; \\
<50 \mathrm{mg} / \mathrm{dL} \\
(<1.3 \mathrm{mmol} / \mathrm{L}) \text { (women) } \\
\text { or drug treatment }\end{array}$ \\
\hline Triglycerides & $\begin{array}{l}\geq 150 \mathrm{mg} / \mathrm{dL} \\
(\geq 1.7 \mathrm{mmol} / \mathrm{L}) \text { or drug } \\
\text { treatment }\end{array}$ & $\begin{array}{l}\geq 150 \mathrm{mg} / \mathrm{dL} \\
(\geq 1.7 \mathrm{mmol} / \mathrm{L}) \\
\text { or drug } \\
\text { treatment }\end{array}$ & $\begin{array}{l}\geq 180 \mathrm{mg} / \mathrm{dL} \\
(\geq 2.0 \mathrm{mmol} / \mathrm{L}) \\
\text { or drug } \\
\text { treatment }\end{array}$ & $\begin{array}{l}\geq 150 \mathrm{mg} / \mathrm{dL} \\
(\geq 1.7 \mathrm{mmol} / \mathrm{L})\end{array}$ & $\begin{array}{l}\geq 150 \mathrm{mg} / \mathrm{dL} \\
(\geq 1.7 \mathrm{mmol} / \mathrm{L}) \text { or drug } \\
\text { treatment }\end{array}$ \\
\hline
\end{tabular}

BMI: body mass index; EGIR: group for the study of insulin resistance; HDL: high-density lipoprotein; IDF: International Diabetes Federation; IR: insulin resistance; NCEP: National Cholesterol Education Program; NHLBI/AHA: National Heart, Lung and Blood Institute/American Heart Association; WHO: World Health Organization.

(a) South Asia and Chinese patients, waist $\geq 90 \mathrm{~cm}$ (men) or $\geq 80 \mathrm{~cm}$ (women); Japanese patients, waist $\geq 90 \mathrm{~cm}$ (men) or $\geq 80 \mathrm{~cm}$ (women).

(b) Insulin resistance measured using insulin clamp.

(c) Asian patients, waist $\geq 90 \mathrm{~cm}$ (men) or $\geq 80 \mathrm{~cm}$ (women).

obstructive sleep apnea, hyperuricemia, and, in particular, chronic kidney disease (CKD).

Chronic kidney disease is an important risk factor for End-Stage Renal Disease (ESRD), CVD, and premature death [27-31] and has become a global public health problem, with increasing social and economic impact due to its high prevalence $[32,33]$. Indeed, almost $5 \%$ of adult Americans have CKD but only a minority reach ESRD, suggesting that most of these patients die of other causes, such as CVD $[26,33,34]$. The possible association between MS and CKD, in light of the growing epidemic of obesity, could represent a window of opportunity to identify individuals at risk of CKD (and, evidently, CVD) and to improve the burden of these diseases through early detection and prevention.

Herein, we aim to critically review the existing clinical evidence that associates MS with renal disease and CVD, as well as the possible pathophysiologic mechanisms involved and actual treatment options.

\section{Chronic Kidney Disease and Cardiovascular Disease}

Chronic kidney disease is an independent risk factor for CVD and all cause-mortality and is considered a coronary heart disease risk equivalent [35-37]. In patients with CKD stage 2 or higher, there is a direct relationship between the degree of renal function impairment and cardiovascular risk, independent of other known risk factors (age, blood pressure, diabetes, and smoking), history of CVD, and presence of proteinuria [36]. Even subtle reductions in renal function, in apparently healthy persons, increase the risk of cardiovascular morbidity and mortality $[37,38]$.

The main factors pointed out as responsible for this increased risk include volume overload and anemia leading to left ventricular hypertrophy, bone mineral disease causing valvular and vascular calcification, inflammation, oxidative stress, endothelial dysfunction, and sympathetic nervous 
system hyperactivity [39]. Additionally, several epidemiologic studies point to a high prevalence of traditional and non-traditional risk factors for CVD in patients with CKD [35, 40-42]. Moreover, the prevalence and magnitude of major risk factors for coronary heart disease increase as renal failure progresses (e.g., hypertension, insulin resistance, and hyperhomocysteinemia) [43].

The prevalence of left ventricular hypertrophy and congestive heart failure is strikingly elevated in patients with CKD stages 2 through $5[44,45]$. Morbidity and mortality for congestive heart failure and coronary heart disease are also excessive in CKD [45-48]. For example, in the large Study of Left Ventricular Dysfunction (SOLVD) Trial, moderate renal impairment was associated with a $41 \%$ increased risk for all-cause mortality, explained largely by heart failure, death and hospitalization [49]. Even in acute coronary syndromes, an estimated creatinine clearance less than $70 \mathrm{~mL} / \mathrm{min}$ was associated with a $20 \%$ increase in mortality in both ST and non-ST elevation myocardial infarction [50].

The close relationship between CVD and CKD may be a manifestation of similar disease processes involved. Indeed, cardiovascular and renal diseases have many types of markers in common, including: clinical, pathophysiologic (e.g., increased angiotensin II activity, upregulation of inflammatory and fibrosis producing cytokines), histopathologic (e.g., inflammatory infiltrates, vascular remodeling), biochemical (e.g., c-reactive protein, homocysteine, lipoprotein (a) and fibrinogen), acute and chronic inflammation and subclinical signs of atherosclerosis (e.g., increased common carotid artery intima-media thickness) [51-59].

It is not surprising, then, that the MS, a constellation of cardiovascular risk factors with well established impact in the incidence of CVD and type II diabetes mellitus, might be associated with the development and progression of CKD.

\section{Metabolic Syndrome and Chronic Kidney Disease}

3.1. Metabolic Syndrome as Risk Factor for Renal Disease. All the components of the MS have individually been associated with the incidence and progression of CKD. The mechanisms and impact of hypertensive and diabetic injuries, the two major etiologies of CKD in the world, have been well studied and described [60-62]. Obesity has also been associated with increased risk for ESRD in several epidemiological studies $[63,64]$. Dyslipidemia, in particular atherogenic dyslipidemia (low HDL cholesterol, high triglycerides), has also been shown to be an independent risk factor for the development and progression of CKD in observational studies and meta-analysis [42, 65-67].

The clustering of all these risk factors should identify individuals at high risk for CKD. Over the last decade a growing body of clinical evidence addressed this issue.

Several observational studies found that individuals with the MS are at increased risk for presenting renal manifestations, namely, microalbuminuria and decreased glomerular filtration rate (GFR). In fact, epidemiologic studies have linked the MS with an increased risk for microalbuminuria, an early marker of glomerular injury and endothelial dysfunction [68-73]. A cross-sectional survey of nondiabetic native Americans that was conducted by Hoehner et al. [70] found that, after controlling for social, demographic, and comorbidity factors, the patients with one to two and those with three or more traits of the MS were $80 \%$ and $130 \%$ more likely to have microalbuminuria than those without MS, respectively. Chen et al. [68] corroborated these findings in another cross-sectional analysis with data from 6125 individuals extracted from the National Health and Nutrition Examination Survey (NHANES) III databasethe multivariate-adjusted odds ratio for microalbuminuria in participants with the MS compared with participants without MS was 1.89 (1.34-2.67), and the risk increased with the number of components of the MS.

Similarly, a number of observational studies evaluated the association of MS and CKD (Table 2) [68, 73-81]. Almost all of them found a significant association between MS and CKD and consistently demonstrated an increased risk parallel to the number of MS traits $[68,74,77,79]$. However, the majority of the studies were cross-sectional and, as so, unable to establish a cause-and-effect relationship, remaining unclear if the MS is a cause or a consequence of the reduced kidney function. In fact, some reports suggest that renal dysfunction perse, even in early stages, is a cause of insulin resistance and MS which increases as the nephropathy progresses $[82,83]$. Additionally, experimental work indicates that uremia is a cause of insulin resistance rapidly reversible by peritoneal dialysis or hemodialysis, further suggesting the presence of a low-molecular-weight substance that functions as an insulin desensitizer in uremia [84]. On the other hand, most of these studies included patients with diabetes and hypertension, two known risk factors for the development and progression of CKD, further impairing the analysis.

In order to address the issues of causality and impact of MS in the development of CKD, two relatively large longitudinal studies, that excluded diabetic patients at baseline, were published to date $[74,76]$. Rashidi et al. showed an $88 \%$ (OR 1.88 ; $1.26-2.8$ ) increased risk for CKD in patients with MS compared to those without, after a 3-year followup period [76]. However, when hypertensive patients at baseline were excluded from the analysis the increased risk was wiped out (OR 0.92; 0.446-1.917). Probably, the most significant study to date was published by Kurella et al., given its large database and long followup period [74]. In this study, the significant association between the MS and subsequent development of CKD was confirmed (OR 1.43; 1.18-1.73). Moreover, this association remained true after excluding patients with hypertension at baseline (OR 1.46; 1.08-1.97) and patients with incident hypertension or diabetes during the followup (OR 1.24; 1.01-1.51), although with marginal statistical significance. However, even when hypertensive patients were excluded at baseline, the patients with MS had statistically significant higher blood pressure within the normal range (at baseline and at the end of followup) than the ones without MS, making it impossible to exclude the effect of hypertension. Additionally, in this and other studies $[68,73,76]$ hypertension was the individual MS trait with 
TABLE 2: Studies that evaluated the association between the metabolic syndrome and chronic kidney disease.

\begin{tabular}{ll}
\hline Study & Design \\
\hline $\begin{array}{l}\text { Chen et al.; Ann Intern Med } \\
2004 \text { [68] }\end{array}$ & $\begin{array}{l}\text { Observational, cross-sectional N =6217 } \\
\text { American adults (database: NHANES III) }\end{array}$ \\
\hline & \\
$\begin{array}{l}\text { Kurella et al., J Am Soc } \\
\text { Nephrol 2005 [74] }\end{array}$ & $\begin{array}{l}\text { Observational, longitudinal (followup 9 yrs) } \\
\text { (database: ARIC Study) }\end{array}$
\end{tabular}

Results

OR for CKD 2.60 (CI: 1.68-4.03)

OR for 2, 3, 4 or 5 traits of MS: 2.21 (CI: 1.16-4.24),

3.38 (C: $1.48-7.69), 4.23$ (CI: 2.06-8.63), and 5.85 (CI: $3.11-11.0)$, respectively.

OR for CKD 1.43 (CI: 1.18-1.73)

OR for CKD associated with 1, 2, 3, 4 or 5 traits of MS:

Kurella et al., J Am Soc (database: ARIC Study)
1.13 (CI: 0.89-1.45), 1.53 (CI: 1.18-1.98), 1.75 (CI:

$1.32-2.33), 1.84$ (95\% CI, 1.27-2.67), and 2.45 (CI:

$1.32-4.54)$, respectively.

OR for CKD (excluded pts with DM or HT during followup) 1.24 (CI: 1.01-1.51)

$\begin{array}{ll}\text { Tanaka et al., Kidney Int } & \text { Observational, cross-sectional } N=6980 \\ 2006 \text { [75] } & \text { Japanese adults }\end{array}$

Rashidi et al., Clin J Am Soc Observational, longitudinal (followup 3 yrs) Nephrol 2007 [76] N $\quad N=4607$ non-diabetic (database: TLGS Study)

Chen et al., Nephrol Dial Transplant 2007 [77]

Observational, cross-sectional $N=15160$ chinese adults (database: inter-Asia study)

OR for CKD 1.54 (CI: 1.28-1.85)

Association only significant for participants younger than $60 \mathrm{y} / \mathrm{o}$.

OR for CKD 1.88 (CI: 1.26-2.8)

OR for CKD (excluded pts with HT) 0.92 (CI: 0.446-1.917)

OR for CKD 1.64 (CI: 1.16-2.732)

OR for CKD associated with 1, 2, 3 and $4+5$ traits of MS: 1.51 (CI: 1.02-2.23), 1.50 (CI: 0.97-2.32), 2.13 (CI: $1.30-3.50)$, and 2.72 (CI: 1.50-4.93), respectively. OR for CKD (excluded pts with HT) 1.74 (CI: $1.00-3.02)$

OR for CKD (excluded pts with DM) 1.46 (CI: $1.02-2.07)$

\begin{tabular}{|c|c|c|}
\hline $\begin{array}{l}\text { Zhang et al., Mayo Clin } \\
\text { Proc } 2007 \text { [73] }\end{array}$ & $\begin{array}{l}\text { Observational, cross-sectional } N=2310 \\
\text { chinese adults }\end{array}$ & $\begin{array}{l}\text { OR for CKD } 1.74 \text { (CI: } 1.32-2.30) \\
\text { OR for CKD (excluded pts with HTor DM) } 2.03 \text { (CI: } \\
1.05-3.94)\end{array}$ \\
\hline $\begin{array}{l}\text { Kitiyakara et al., Kidney Int } \\
2007 \text { [78] }\end{array}$ & $\begin{array}{l}\text { Observational, cross-sectional with a } \\
\text { longitudinal subgroup (followup } 12 \text { yrs) } N= \\
3195 \text { Southeastern Asians (subgroup 2067) }\end{array}$ & $\begin{array}{l}\text { OR for CKD } 2.48 \text { (CI: 1.33-4.62)-cross-sectional } \\
\text { OR for CKD } 1.62 \text { (CI: 1.00-2.61)-longitudinal } \\
\text { Association only significant with the NCEP ATP III } \\
\text { criteria, not the IDF criteria }\end{array}$ \\
\hline $\begin{array}{l}\text { Luk et al., Diabetes Care } \\
2008 \text { [79] }\end{array}$ & $\begin{array}{l}\text { Observational, longitudinal (Mean followup } \\
4.6 \text { yrs) } N=5829 \text { diabetic type II pts } \\
\text { (database: Hong Kong Diabetes Registry) }\end{array}$ & $\begin{array}{l}\text { OR for CKD } 1.31 \text { (CI: } 1.12-1.54) \\
\text { OR for CKD associated with } 2,3,4 \text { or } 5 \text { traits of MS: } \\
1.15(0.83-1.60), 1.32(0.94-1.86), 1.64(1.17-2.32) \text {, } \\
\text { and } 2.34(1.54-3.54) \text {, respectively. }\end{array}$ \\
\hline $\begin{array}{l}\text { Jang et al., J Public Health } \\
2010[80]\end{array}$ & $\begin{array}{l}\text { Observational, cross-sectional } N=5136 \\
\text { Korean adults (Database: KNHANES III) }\end{array}$ & OR for CKD $1.77(P<.05)$ \\
\hline $\begin{array}{l}\text { Yu et al., Nephrol Dial } \\
\text { Transplant } 2010 \text { [81] }\end{array}$ & $\begin{array}{l}\text { Observational, cross-sectional } N=5911 \\
\text { Korean adults (Database: KNHANES III) }\end{array}$ & $\begin{array}{l}\text { OR for CKD: NS } \\
\text { Association only significant in men younger than } 60 \mathrm{y} / \mathrm{o} \\
\text { and postmenopausal women. }\end{array}$ \\
\hline
\end{tabular}

ARIC: Atherosclerosis Risk in Communities; CI: Confidence Interval; CKD: Chronic Kidney Disease; DM: Diabetes Mellitus; HT: Hypertension; IDF: International Diabetes Federation; KNHANES: Korean National Health and Nutrition Examination Survey; MS: Metabolic Syndrome; NCEP ATP: National Cholesterol Education Program Adult Treatment Panel; NHANES: National Health and Nutrition Examination Survey; NS: no significance; OR: Odds Ratio; TLGS: Tehran Lipid and Glucose Study.

the strongest association to CKD, even stronger than the MS itself. The same consideration is valid for hyperglycemia in some studies $[68,73,77]$. As Bakker et al. elegantly demonstrated the problem with the concept of MS, as a way to predict renal (and CVD) risk, is the dichotomization of continuous variables and clustering correlated risk factors, resulting in a significant loss of predictive power [85]. A study of Kitiyakara et al. has even suggested that the risk of CKD associated with the MS was different accordingly to the definition of MS used [78].
Although the results of these studies suggest there is a close association between MS and renal disease, two questions still do persist Does the MS add any relevant additional information in terms of renal risk? Are there specific pathophysiologic mechanisms of renal injury in the MS? Kurella et al. also found that there were graded relations among the number of MS traits, the Homeostasis Model Assessment (HOMA)-insulin resistance, fasting insulin levels and the risk for $\mathrm{CKD}$, suggesting a pathophysiologic basis for their findings [74]. Similar associations were previously 
reported by Chen et al. [86]. These findings indicate that that the MS directly contributes to the development of CKD and the claimed pathophysiologic link is obesity, a hallmark of the MS. Part of the explanation is, in fact, the link between obesity, diabetes and hypertension [85]. However, obesity (in particular visceral obesity) has independently been associated with the risk of CKD and ESRD [63, 64, $68,76,87]$, even when corrected for these two indirect mechanisms and proteinuria, suggesting the existence of additional direct pathomechanisms.

3.2. Pathophysiology and Pathology of Renal Disease in Metabolic Syndrome. Many studies evaluated the mechanisms by which the factors in MS mediate pathological and pathophysiological changes in the kidney. The underlying mechanisms are still not completely understood but include insulin resistance itself, inflammation, renal endothelial dysfunction, oxidative stress, altered renal heamodynamics, activation of the reninangiotensin-aldosterone system (RAAS) and sympathetic nervous system (SNS), and dietary factors.

3.2.1. Inflammation and Insulin Resistance. Inflammation has been implicated in MS pathogenesis, especially as a mechanism of insulin resistance and endothelial dysfunction [88]. As mentioned, genetic and environmental factors lead to central obesity. This enlarged mass of adipocytes plays a vital role in the pathophysiology of MS. There is increased flux of free fatty acids into the liver leading to excessive hepatic production of triglycerides and resultant hypertriglyceridemia. Moreover, the adipocytes also secrete inflammatory cytokines (e.g., MCP-1, TNF- $\alpha$, IL6 , leptin and $\mathrm{C}$ reactive protein), while there is relative deficiency of the anti-inflammatory and antiatherogenic cytokine adiponectin, resulting in a low-grade inflammatory state thought to be responsible for insulin resistance and endothelial dysfunction [89]. At the molecular level, the link between inflammation and insulin resistance has already started to be elucidated [90-92], but is over the scope of this article.

The role of chronic inflammation in renal pathophysiological changes in the setting of MS, driven both by proinflammatory cytokines and adipocytokines, is not clear. As stated, in obesity, the adipocyte-derived adiponectin, an insulin-sensitizing anti-inflammatory protein, is decreased along with an increase in the plasma levels of leptin. Increased adipokines have been shown to directly contribute to insulin resistance but their effects on CKD have not been examined. However, adipokines such as leptin can cause renal vascular remodeling and disruption of renal function. Some evidence indicates that leptin may represent a link between obesity and increased sympathetic activity, through its action on the hypothalamus, to increase blood pressure [93]. It has also been shown that increased levels of TNF- $\alpha$ promote generation of reactive oxygen species (ROS) in glomerular cells and proximal tubular cells. These ROS contribute to renal injury in several ways like inducing renal endothelial dysfunction and microalbuminuria, matrix accumulation, mesangial expansion, and fibrosis [94, 95].

Within the kidney, insulin resistance and hyperinsulinemia associated with MS seem to induce local inflammation, an important pathophysiological pathway for CKD. Insulin may induce renal fibrosis through stimulation of mesangial cells and proximal tubule cells to produce TGF-b [96, 97]. Moreover, insulin stimulates the production of IGF-1 by vascular smooth muscle cells and other cell types, which has been implicated in the development of diabetic kidney disease [98]. IGF-1 increases the activity of connective tissue growth factor, a cytokine that has profibrogenic actions on renal tubular cells and interstitial fibroblasts. In addition, IGF-1 decreases the activity of matrix metalloproteinase-2, an enzyme responsible for extracellular matrix degradation, thereby promoting extracellular matrix expansion and renal fibrosis [99, 100]. Additionally, insulin resistance promotes sodium and uric acid reabsorption, resulting in salt-sensitive hypertension and hyperuricemia [88]. In the end, at the glomerular level, insulin resistance and the release of inflammatory cytokines induce mesangial expansion, basement membrane thickening, podocytopathy and loss of slit pore diaphragm integrity, leading to the so-called "obesity-related glomerulopathy" $[89,101]$. This condition is characterized by a specific histopathologic pattern of glomerulomegaly (100\% of cases), frequently accompanied by focal segmental glomerulosclerosis (80\% of cases), and has been repeatedly described in obese patients without any other defined primary or secondary glomerular diseases (including diabetic nephropathy, hypertensive nephrosclerosis, and secondary focal segmental glomerulosclerosis). This glomerulopathy has pathologic features strikingly resembling the ones induced by diabetes and/or hypertension and, similarly, has a progressive clinical course. Of particular concern, the biopsy incidence of this condition had a 10-fold increase over a period of 15 years [101] and has been observed in children as young as 3 years of age $[101,102]$.

3.2.2. Renal Haemodynamics. The consistent observation of glomerulomegaly raised the hypothesis that glomerular hyperfiltration was a major mechanism in the pathogenesis of obesity-related glomerulopathy. This was first elucidated in an animal model, the obese Zucker rat, which has hyperphagia due to a defect in the brain leptin receptor, resulting in obesity and associated hyperglycemia, hyperinsulinaemia, insulin resistance, dyslipidaemia and hypertension, thus closely mimicking MS in humans. This model has glomerular hyperfiltration and develops albuminuria, which progress to renal failure with histological characteristics of glomerulomegaly and focal and segmental glomerulosclerosis [103]. These findings have elegantly been confirmed in humans by Chagnac et al. [104, 105]. These authors demonstrated that obese patients, with clinical characteristics consistent with the diagnosis of MS, had a 50\% and 30\% increase in GFR and renal plasma flow (RPF), respectively, as compared to lean controls, resulting in increased filtration fraction, an indirect indicator of glomerular hypertension [104]. Moreover, when 17 morbidly obese patients who lost an average of $48 \mathrm{~kg}$ 
at 1 year after bariatric surgery, postprandial GFR and RPF were significantly decreased and approached normal levels, even though the patients were still obese [105]. In a relatively recent study with young (mean age 18 years) healthy males, MS was associated with a 6.9-fold increase in the OR of glomerular hyperfiltration [106]. The authors concluded that glomerular hyperfiltration has an early-onset in life, before any manifestations of CVD, and so may be a marker of metabolic risk. It is well known that hyperfiltration (even in nondiabetic patients) leads to albuminuria (a well established cardiovascular and renal risk factor), which is consistent with the aforementioned epidemiologic studies that showed a graded prevalence of microalbuminuria according to the number of MS traits [68-73]. Besides the known effect of hyperglycemia, these renal haemodynamic changes have been attributed in experimental studies to a higher intake of dietary protein in these individuals [107-109]. The amino acid excess induces a profibrotic and proliferative mesangial injury response, mediated by increased formation of advanced glycation end-products, presumably the result of greater availability of free amino groups for glycation reactions $[110,111]$.

3.2.3. Oxidative Stress. The presence of renal oxidative stress has been documented in animal models of insulin resistance, diabetic patients, and patients with CKD of various etiologies $[112,113]$.

High glucose and free fatty acid increase mitochondrial ROS in renal endothelial cells, which may contribute to tissue dysfunction by dysregulation of redox-sensitive signaling pathways or by oxidative damage to biological structures (DNA, proteins, lipids, etc.) [114].

Lipid peroxidation, a well-known consequence of excessive ROS, is the first step in the generation of oxidized LDL, which accumulates in renal mesangial cells and form foam cells [115]. Lipid peroxidation also induces endothelial damage and inflammatory response, impairs vasodilatation and activates macrophages [116, 117]. Lipid peroxidation itself generates more free radicals and ROS thereby increasing the potential for renal injury.

Additionally, the aforementioned glomerular hyperfiltration may also be caused by mitochondrial ROS, through the activation of cyclooxygenase-2 gene transcription followed by prostaglandin E2 overproduction and preglomerular vasodilation [114]. Furthermore, excessive oxidative stress stimulates the synthesis of angiotensin II (via the nuclear factor-kB pathway), which further increases glomerular hypertension and hyperfiltration by causing efferent arteriole vasoconstriction. Angiotensin II also stimulates the synthesis of TGF-b, thereby promoting glomerular fibrosis [118].

Moreover, ROS-dependent b-cell damage is thought to be involved in the progression from MS to type II diabetes mellitus [119] and ROSs enhance the formation of advanced glycation end products [120], which have a major pathophysiologic role in the development of diabetic nephropathy.

3.2.4. Endothelial Dysfunction. Dysfunction of the vascular endothelium is an important factor in the pathogenesis of diabetic nephropathy and has its clinical counterpart in microalbuminuria [121, 122].

Available evidence indicates that the insulin-receptor signaling pathway mediating glucose uptake in vascular endothelium requires stimulation of endothelial nitric oxide (NO) synthase and subsequent NO production [123], a potent vasodilatory and antithrombotic substance. Comparable endothelial responses-enhanced NO production with vasodilation - are induced by adiponectin [124]. These actions mediate a hemodynamic component of energy distribution, enhancing tissue blood flow to optimize nutrient delivery. In insulin-resistant states, such as obesity, MS and type 2 diabetes mellitus, insulin- (and adiponectin-) induced NO production and endothelium-dependent vasodilatation are impaired, representing one of several mechanisms linking abdominal obesity/insulin resistance and hypertension [125127]. Additionally, excessive oxidative stress further decreases NO production and availability thereby contributing to endothelial dysfunction in diabetic and MS patients [120].

Another product of endothelial cells, endothelin-1, has been implicated in CVD, hypertension and several kidney diseases. Insulin stimulates the secretion of endothelin 1 from glomerular endothelial, mesangial and vascular smooth muscle cells through the insulin receptor. Endothelin-1 is associated with severe intrarenal vasoconstriction, reduced GFR, mesangial cell contraction and proliferation and sodium and water retention [128-130]. Patients with the MS are hyperinsulinemic, suggesting that endothelin-1 may be involved in the development of nephropathy in these patients.

3.2.5. Fructose. Recently, another dietary factor-fructosehas been implicated in the pathophysiology of MS, and could establish the link between modern dietary patterns, systemic inflammation, MS and cardiovascular and renal disease progression [131]. Fructose is a simple sugar that is a component of table sugar as well as of high fructose corn syrup, which is a universally used sweetener. Fructose consumption has increased markedly worldwide during the last several decades, which correlates closely with the increasing incidence of obesity and MS [132]. The administration of fructose to both animals and humans has been showed to induce most of the features of MS $[133,134]$. This is clinically relevant as some studies have reported that adolescents can easily ingest 15\%-20\% of their energy intake as fructose [135]. In recent years, experimental evidence associating fructose and systemic inflammation has accumulated, pointing out an increased expression of leukocyte adhesion proteins (ICAM-1) and chemokines (MCP-1) in various cell types (endothelial, proximal tubular, and vascular smooth muscle cells) [131]. The underlying mechanism appears to be related to increased uric acid generation and resulting hyperuricemia. Uric acid has been shown to induce oxidative stress, reduce nitric oxide generation, stimulate the local renin-angiotensin system and induce expression of proinflammatory chemokines, resulting in a significant increase in renal injury and inflammation [136-139]. These recent insights into the pathophysiology 
may represent new treatment opportunities (e.g., reduction of dietary fructose, uric acid lowering agents or, in the future, blocking the signaling pathways driving the response), as there is increasing evidence that systemic inflammation may increase the risk of cardiovascular outcomes and progression of renal disease [140-142].

3.2.6. Sympathetic Nervous System and Renin-AngiotensinAldosterone System. Finally, the sympathetic nervous system (SNS) and the renin-angiotensin-aldosterone system (RAAS) are considered important pathophysiologic factors in the development of MS, which can also contribute to the high cardiovascular risk associated with it. Some studies have associated plasma aldosterone levels with insulin resistance and MS, in both normotensive and hypertensive patients [143-145]. Angiotensin II is thought to have a role in the development of insulin resistance by inducing oxidative stress and also in the development of salt-sensitive hypertension by promoting sodium reabsorption, which could explain the benefits of blocking the RAAS on prevention of new cases of diabetes [146].

In summary, apart from the effect of hypertension and diabetes, there are other contributing factors for development of kidney injury in MS. These include oxidative stress and systemic inflammation (probably induced by dietary factors like fructose and adipose tissue-derived cytokines), endothelial dysfunction, altered renal hemodynamics (partially as the result of high dietary protein intake), excessive renal sodium reabsorption, activation of the RAAS and SNS, atherogenic lipid profile, and even physical compression of the kidneys by adipose tissue. Complex interactions between all these factors ultimately lead to glomerular hyperfiltration, glomerular cell proliferation, matrix accumulation, and, finally, glomerulosclerosis and progressive loss of nephrons.

3.3. Prevention of Renal Disease in Metabolic Syndrome. The association between MS and renal disease raises the question whether treating the components of the syndrome could prevent renal injury. Interventional randomized controlled trials addressing renal endpoints in the specific setting of MS have not been published to date. However, each diagnostic criterion of MS identifies a risk factor for CVD that requires intervention independently of its contribution to $\mathrm{CKD}$ incidence or progression. Although the value of a multifactorial intervention for preventing cardiovascular events and CKD in the setting of MS has not been examined, it has already been proposed [147]. According to this strategy, upon the diagnosis of MS, clinicians should implement a multitargeted intervention with treatment goals based on global CVD risk assessment (using, e.g., the 10-year Framingham risk score or the European risk SCORE chart and the estimated GFR). This multidimensional intervention should focus simultaneously on life-style changes, glycemic and blood pressure control, lipid lowering, and other proven beneficial treatments, like antiplatelet therapy (Figure 1).

The value of simultaneous management of multiple risk factors has been tested in type II diabetic patients (a group for which MS is intended to be a high risk factor), resulting in a lower risk of CVD and nephropathy in the intensive treatment group (stepwise implementation of behavior modification and pharmacologic therapy with strict treatment targets for hyperglycemia, hypertension, dyslipidemia, and microalbuminuria, plus secondary prevention of cardiovascular disease with aspirin; treatment overseen by a project team) compared to conventional treatment (treatment for multiple risk factors from their general practitioner, according to current recommendations, with the possibility of being referred to specialists) [148]. Moreover, it has been shown in this group of patients that intensive blood pressure $(<130 / 80 \mathrm{~mm} \mathrm{Hg})$ and blood glucose control (aiming at glycated hemoglobin level $6.5 \%$ ) effectively prevent cardiovascular events, the development of microalbuminuria, and overt nephropathy $[149,150]$. Despite that, the Action to Control Cardiovascular Risk in Diabetes Study Group (ACCORD) trials alert us that treating diabetic patients to normal values (systolic blood pressure $<120$ and glycated hemoglobin level 6.0\%) may not be beneficial and increase the risk of adverse events $[151,152]$. These studies reinforce the notion that aggressive, although cautious, multitargeted management of the MS may confer protection for CVD and CKD [147]. In fact, several lines of evidence indicate that interventions directed at each component of the MS can protect the kidney.

3.3.1. Therapeutic Lifestyle Changes. Lifestyle modifications, including physical activity and dietary interventions, with the objective of weight loss are a cornerstone of therapy [1]. Physical activity and weight reduction improve insulin resistance even in people with renal impairment and ESRD [153]. Small weight reductions have been shown to have significant beneficial effects. A weight loss of $5 \%-10 \%$ of initial body weight has lowered the risk for diabetes and CVD, as well as significant $(P=.001)$ improvements in related modifiable risk factors, including $\mathrm{HbAlc}$, HDL cholesterol, triglycerides, and systolic and diastolic blood pressure [154].

Beneficial renal effects, like reduction of glomerular hyperfiltration and albuminuria, have been demonstrated after weight loss (either through diet or bariatric surgery) $[105,155]$, although these results still need to be demonstrated by properly designed clinical trials. Additionally, the impact on renal outcomes resulting from improved insulin resistance through pharmacologic weight loss [156] or the Mediterranean diet [157] has not been studied. Moreover, in light of what is known about renal hemodynamics (see above), the safety of the so popular "high-protein lowcarbohydrate" weight reduction diet should also be analyzed. Finally, the potential effects of dietary fructose reduction in the incidence of MS and its renal and cardiovascular consequences represent an exciting field of research in the near future.

We strongly believe that a reasonable goal for obese patients with the MS would be a weight loss of $5-10 \%$ of body weight, through an effective ongoing program that includes an increase in physical activity to at least $150 \mathrm{~min} /$ week of moderate exercise, similar to the recommendations for prevention of type II diabetes mellitus in 


\section{"Screening" for CVD risk factor clustering}<smiles>CCCCCCC</smiles>

Diagnosis of MS<smiles>C1CCCCC1</smiles>

CVD risk global assessment

(10-year Framingham risk score, European risk SCORE chart; GFR; OGTT in selected patients)

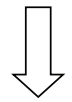

Multi-factorial (multi-dimensional) management

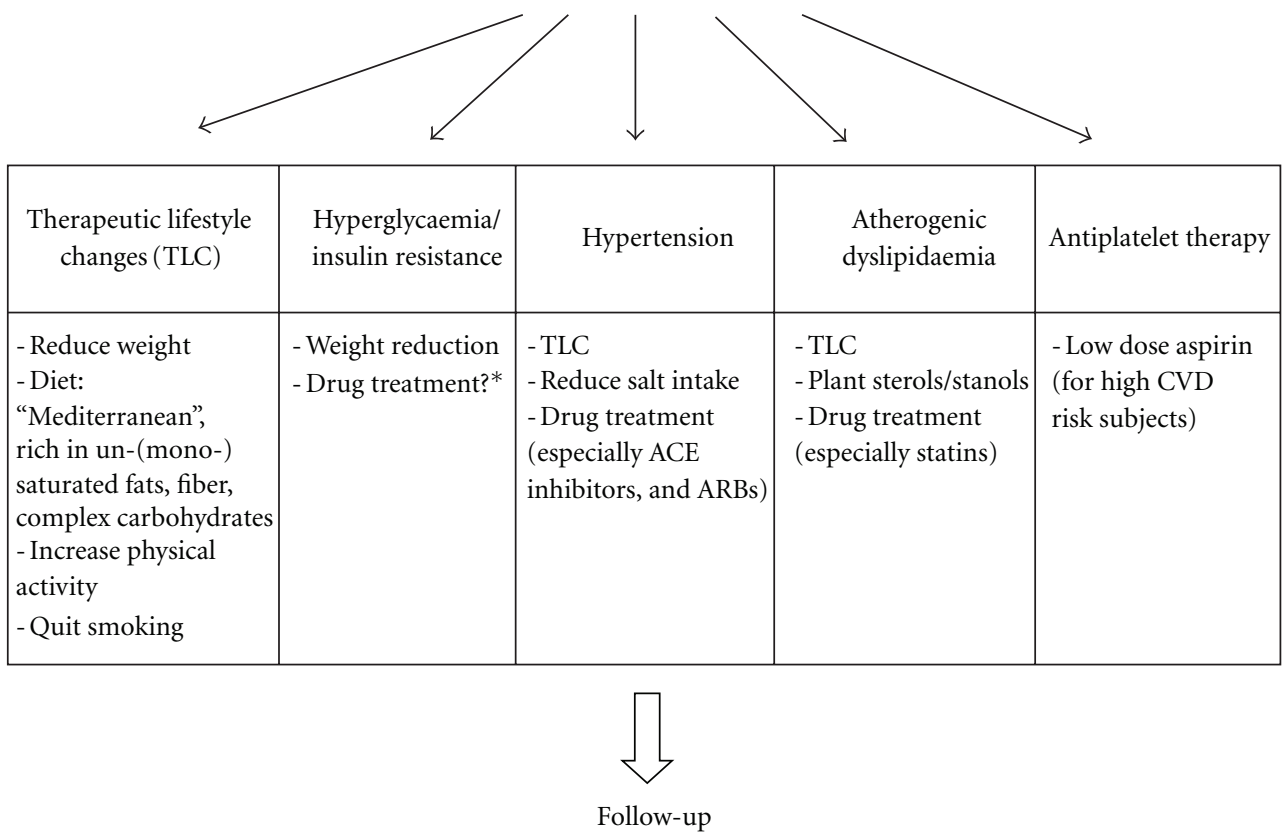

TLC evaluation; adherence to treatment; clinical and laboratory assessment of targeted therapy (blood pressure, lipid profile, glycemic control, renal function testing)

FIGURE 1: Management of the metabolic syndrome [147] (reproduced with permission). ACE: angiotensin converting enzyme; ARBs: angiotensin II receptor antagonists; CVD: cardiovascular disease; GFR: glomerular filtration rate; MS: metabolic syndrome; OGTT: oral glucose tolerance test.

patients with impaired glucose tolerance (IGT) or impaired fasting glucose (IFG) [158].

3.3.2. Blood Pressure Control. As mentioned, intensive treatment of diabetes and hypertension has been shown to improve renal outcomes in diabetic patients. Moreover, blocking the RAAS is extensively recommended as firstline anti-hypertensive therapy for renal and cardiovascular protection, especially in diabetic and/or proteinuric patients $[159,160]$. Given the aforementioned role of RAAS activation in the pathophysiology of the MS and the importance of hypertension on CKD risk in the setting of MS, we should expect great impact of RAAS blockers on the development of kidney injury. This, however, has never been studied. Nevertheless, angiotensin-converting enzyme inhibitors and angiotensin receptor blockers should be the preferred antihypertensive drugs in patients with MS as in diabetics [161]. On the other hand, the use of thyazide diuretics and b-blockers should be avoided (or restricted to treatment of resistant hypertension) in patients with MS due to the risk of newonset diabetes [162].

The therapeutic goal should be established according to the global cardiovascular risk, as recommended by the latest guidelines [162]. In general, given that the MS is a constellation of CVD risk factors (implying the presence of at least two traits) and often with subclinical organ damage, a blood pressure lower than 130/80 $\mathrm{mm} \mathrm{Hg}$ should be attained in most patients [162]. Probably, for renal protection, a lower target $(<120 / 75 \mathrm{~mm} \mathrm{Hg})$ is beneficial in highly proteinuric patients (>1 gr/day) [163]. However, 
as mentioned before, bringing systolic blood pressure to normal values $(<120 \mathrm{~mm} \mathrm{Hg})$ may increase treatment sideeffects without additional benefit, especially in patients with advanced atherosclerotic disease [152].

3.3.3. Glycemic Control. Given the known impact of diabetes in the development and progression of CKD, glycemic control in diabetic patients or preventing/delaying new-onset type II diabetes mellitus is a main goal of therapy in patients with MS. The use of agents that improve insulin sensitivity, like metformin or thiazolidenidiones, is of great interest but also raises some concerns. Metformin has been shown to reduce the incidence of both type II diabetes mellitus and MS in subjects with IGT. However, metformin was less effective than intensive lifestyle modification (regular physical activity and low-fat diet) $[164,165]$. Despite its beneficial effects, metformin is contraindicated in CKD patients with creatinine clearance lower than $60 \mathrm{~mL} / \mathrm{min}$ due to the risk of severe lactic acidosis. Thiazolidenidiones (peroxisome proliferator activator receptor- $\gamma$ agonists), another class of antidiabetic agents with insulin sensitizing properties, have multiple pleotropic effects that, in theory, are of great interest in the setting of MS. They reduce blood pressure and modulate dyslipidaemia, inflammation, oxidative stress, endothelial dysfunction, fibrosis and remodelling, and glomerular cell proliferation, and reduce urine albumin excretion [166]. Moreover, thiazolidenidiones also reduce the incidence of type II diabetes mellitus in prediabetic subjects [167]. However, their use causes weight gain and fluid retention, an undesirable effect especially for obese subjects and some drugs of this class have been associated with an increased incidence of myocardial infarction [168].

Other classes of antidiabetic drugs have been shown to improve cardiovascular risk profile in diabetic and prediabetic patients, beyond glycemic control [169]. Drugs that promote weight loss, improve control of other cardiovascular risk factors (like blood pressure and lipid profile) or that produce beneficial effects in surrogate markers of subclinical atherosclerosis, are very attractive in the setting of MS. For example, in a systematic review, the old alpha-glucosidase inhibitors have been shown to produce a modest weight reduction $(-1.2 \mathrm{Kg})$ as well as improvements in total cholesterol, LDL cholesterol, triglycerides, systolic and diastolic blood pressure in patients with IGT and/or IFG [170]. Additionally, in the same group of patients, acarbose was associated with a significant reduction in the progression of carotid intima-media tickness (IMT) compared to placebothe annual progression of IMT was reduced by $50 \%$, with a mean followup of 3.9 years [171]. More importantly, in the Study to Prevent Non-Insulin-Dependent Mellitus (STOP-NIDDM), also in patients with IGT, acarbose was found to reduce the risk of developing any cardiovascular event by $49 \%$ with an absolute risk reduction of $2.5 \%$ [172].

On the opposite time-line end, also the new incretin mimetics-Glucagon-like peptide-1 (GLP-1) receptor agonists and Dipeptidyl peptidase-4 (DPP-4) inhibitors-have beneficial pleotropic effects on various MS traits. GLP1 receptor agonists are associated with progressive, dosedependent weight loss in patients with type 2 diabetes [173] while the DPP-4 inhibitors are generally considered weight neutral [169]. Exenatide, a GLP-1 receptor agonist, has been shown to produce significant reductions in total cholesterol, triglycerides, systolic and diastolic blood pressure in patients with type II diabetes mellitus with the MS [174]. The effect on blood pressure, a major determinant of renal and cardiovascular risk in patients with MS, is very significant and is greater in patients with systolic blood pressure $>130 \mathrm{mmHg}$ $(-11.4 \mathrm{~mm} \mathrm{Hg}$ and $-3.6 \mathrm{~mm} \mathrm{Hg}$ for systolic and diastolic blood pressure, resp.; $P<.05)$ [175]. Similarly, DPP-4 inhibitors also produced favorable trends on lipid levels and systolic and diastolic blood pressure, even in patients without diabetes $[173,176]$. Moreover, GLP-1 receptor agonists were recently associated with improvements in inflammatory state, insulin resistance and beta-cell function as compared to sulfonylureas in patients with type II diabetes [177].

At the present time, there are no data on glycemic control goals in patients with MS who are not diabetic. Both for renal and CVD prevention the obvious treatment goal is to prevent the onset of overt type II diabetes in this group of patients. Current recommendations are to treat patients with IFG, IGT or glycated hemoglobin of $5.7 \%-6.4 \%$ though weight loss and physical activity [158]. Despite their beneficial effects, the use of antidiabetic drugs is actually not recommended in prediabetic subjects [178], maybe with the exception of metformin for patients at very highrisk of developing diabetes (combined IFG and IGT plus other risk factors such as glycated hemoglobin $>6 \%$, hypertension, low HDL cholesterol, elevated triglycerides, or family history of diabetes in a first-degree relative) who are obese and under 60 years of age [158].

For patients with overt type II diabetes mellitus, both for prevention of nephropathy and CVD risk reduction, the recommended goal is to achieve a glycated hemoglobin $<7 \%$, although the available evidence is more compelling for microvascular disease prevention [158]. Moreover, data from large diabetes trials suggest a small but incremental benefit in microvascular outcomes with glycated hemoglobin closer to normal $[150,158,179]$. Therefore, despite the results of the aforementioned ACCORD trial, for renal disease prevention a lower glycated hemoglobin might be pursued in selected patients (those with short duration of diabetes, long life expectancy, and no significant CVD), with close monitoring for hypoglycemia and other adverse effects of treatment [158]. In the setting of MS, the antidiabetic drugs with insulin sensitizing properties and/or with beneficial effects on other cardiovascular risk factors/markers should be considered for first-line therapy.

3.3.4. Dyslipidaemia Correction. Statins are the most widely used agents for dyslipidemia, but their role in the MS has not been well evaluated. Nevertheless, for example, in the Scandinavian Simvastatin Survival Study (4S), among patients with elevated serum LDL-cholesterol and established coronary disease, those with characteristics of the MS 
had both the highest risk of major coronary events and the greatest benefit from statin therapy [180]. Additionally, treatment of patients with known coronary disease and the MS with atorvastatin $(80 \mathrm{mg} /$ day), compared to atorvastatin $(10 \mathrm{mg} /$ day $)$, decreased the rate of major cardiovascular events [181]. The effect of statins on kidney function has been addressed in several clinical studies and metaanalysis. It was demonstrated that statins reduce kidney function loss in CKD patients and reduce albuminuria in microalbuminuric and macroalbuminuric patients [182, 183]. Moreover, statins have been shown to slow down GFR decline in high cardiovascular risk patients with normal or near normal renal function at baseline and the patients with MS were the ones with the greatest benefit [184]. The role of statins for renal protection is attributed to their presumed pleiotropic effects including anti-inflammatory, antifibrotic, antihypertensive, and antioxidant properties.

Fibrates are hypolipidaemic drugs very effective in reducing triglycerides, a major feature of MS. Some studies have suggested an improvement in proteinuria progression on diabetic patients treated with fibrates [185], but their role in preventing CKD in MS patients is still unknown.

For CVD prevention (and probably also for renal disease prevention and/or progression), the goal of therapy for MS patients, as for diabetic patients, should focus primarily in LDL cholesterol. In most cases, patients with MS represent a group with very high added risk for CVD (Framingham 10 year risk $>20 \%$ ), even if they are not diabetic. As so, most patients with MS and all patients with type II diabetes mellitus (a coronary heart disease equivalent) should be treated to a primary treatment goal of LDL cholesterol $<100 \mathrm{mg} / \mathrm{dL}$. In patients with overt CVD, a lower target of $<70 \mathrm{mg} / \mathrm{dL}$ may be considered [158]. For patients with lower CVD risk (Framingham 10 year risk 10\%-20\%), a target of $<130 \mathrm{mg} / \mathrm{dL}$ is considered adequate [9]. Secondary treatment goals, in this population are triglycerides $<150 \mathrm{mg} / \mathrm{dL}$ and HDL cholesterol $>40 \mathrm{mg} / \mathrm{dL}$ in men and $>50 \mathrm{mg} / \mathrm{dL}$ in women. To achieve these goals therapeutic lifestyle changes (with emphasis on weight loss and physical activity) should be implemented, but statin therapy will almost always be necessary and should be started simultaneously with lifestyle changes in high risk patients $[9,158]$.

\section{Conclusions}

The existence of MS as a unique pathophysiologic process and whether it confers risk beyond its individual components have been questioned and are still under debate. Moreover, other clinical variables and risk scores have been proven superior to MS in indentifying individuals at risk for type II diabetes mellitus or CVD $[186,187]$.

Despite that, in the last decade, a growing body of epidemiologic evidence has associated the MS with the risk for developing renal damage, clinically expressed in the form of microalbuminuria and/or CKD. Given the additional association between MS and CVD risk, which can be further aggravated if renal impairment is superimposed, MS represents, at least, a powerful awareness tool for the need to aggressively prevent and manage risk factors. This need is underscored by the epidemic of obesity in the developed world, particularly affecting adolescents and young adults, which can pose in the future a huge burden on the health care system including dialysis facilities [85].

The association between MS and renal damage is, in part, explained by hypertension and impaired glucose metabolism. However, experimental and epidemiologic data suggest that other aspects of the MS are associated with the development of renal abnormalities and should also deserve close attention as they are modifiable risk factors. In particular, prevention of obesity and promotion of healthy lifestyles are likely to be the most effective approaches and should be a public health priority.

An increasing body of evidence suggests that treating each component included in the MS definition can improve renal outcomes. However, it has never been investigated whether treating patients with MS will prevent the development and progression of CKD. Clinical trials, in the setting of MS, to verify whether treating its components may effectively prevent renal impairment should be a priority. These should include trials of weight loss and nutritional strategies (e.g., low protein and low fructose diets) and multitargeted treatment of risk factors (blood pressure and glycemic control, renin-angiotensin system inhibition, lipid lowering and insulin resistance). Finally, the new insights into the pathophysiology of systemic inflammation in the MS can provide, in the future, new treatment targets.

\section{Conflict of Interests}

There is no conflict of interests to declare.

\section{References}

[1] J. E. Manson, P. J. Skerrett, P. Greenland, and T. B. VanItallie, "The escalating pandemics of obesity and sedentary lifestyle: a call to action for clinicians," Archives of Internal Medicine, vol. 164, no. 3, pp. 249-258, 2004.

[2] R. Weiss, J. Dziura, T. S. Burgert et al., "Obesity and the metabolic syndrome in children and adolescents," New England Journal of Medicine, vol. 350, no. 23, pp. 2362-2374, 2004.

[3] G. M. Reaven, "Banting lecture 1988. Role of insulin resistance in human disease," Diabetes, vol. 37 , no. 12, pp. 1595-1607, 1988.

[4] R. A. DeFronzo and E. Ferrannini, "Insulin resistance: a multifaceted syndrome responsible for NIDDM, obesity, hypertension, dyslipidemia, and atherosclerotic cardiovascular disease," Diabetes Care, vol. 14, no. 3, pp. 173-194, 1991.

[5] R. S. Lindsay and B. V. Howard, "Cardiovascular risk associated with the metabolic syndrome," Current Diabetes Reports, vol. 4, no. 1, pp. 63-68, 2004.

[6] K. K. Koh, S. H. Han, and M. J. Quon, "Inflammatory markers and the metabolic syndrome: insights from therapeutic interventions," Journal of the American College of Cardiology, vol. 46, no. 11, pp. 1978-1985, 2005.

[7] K. G. M. M. Alberti and P. Z. Zimmet, "Definition, diagnosis and classification of diabetes mellitus and its complications. 
Part 1: diagnosis and classification of diabetes mellitus. Provisional report of a WHO consultation," Diabetic Medicine, vol. 15, no. 7, pp. 539-553, 1998.

[8] B. Balkau and M. A. Charles, "Comment on the provisional report from the WHO consultation," Diabetic Medicine, vol. 16, no. 5, pp. 442-443, 1999.

[9] J. I. Cleeman, "Executive summary of the third report of the National Cholesterol Education Program (NCEP) expert panel on detection, evaluation, and treatment of high blood cholesterol in adults (adult treatment panel III)," Journal of the American Medical Association, vol. 285, no. 19, pp. 24862497, 2001.

[10] S. M. Grundy, J. I. Cleeman, S. R. Daniels et al., "Diagnosis and management of the metabolic syndrome: an American Heart Association/National Heart, Lung, and Blood Institute scientific statement," Circulation, vol. 112, no. 17, pp. 27352752, 2005.

[11] K. G. M. M. Alberti, P. Zimmet, and J. Shaw, "The metabolic syndrome-a new worldwide definition," Lancet, vol. 366, no. 9491, pp. 1059-1062, 2005.

[12] E. S. Ford, W. H. Giles, and W. H. Dietz, "Prevalence of the metabolic syndrome among US adults: findings from the Third National Health and Nutrition Examination Survey," Journal of the American Medical Association, vol. 287, no. 3, pp. 356-359, 2002.

[13] E. S. Ford, "Prevalence of the metabolic syndrome defined by the international diabetes federation among adults in the U.S," Diabetes Care, vol. 28, no. 11, pp. 2745-2749, 2005.

[14] E. S. Ford, W. H. Giles, and A. H. Mokdad, "Increasing prevalence of the metabolic syndrome among U.S. adults," Diabetes Care, vol. 27, no. 10, pp. 2444-2449, 2004.

[15] P. W. F. Wilson, R. B. D’Agostino, H. Parise, L. Sullivan, and J. B. Meigs, "Metabolic syndrome as a precursor of cardiovascular disease and type 2 diabetes mellitus," Circulation, vol. 112, no. 20, pp. 3066-3072, 2005.

[16] S. D. de Ferranti, K. Gauvreau, D. S. Ludwig, E. J. Neufeld, J. W. Newburger, and N. Rifai, "Prevalence of the metabolic syndrome in American adolescents: findings from the Third National Health and Nutrition Examination Survey," Circulation, vol. 110, no. 16, pp. 2494-2497, 2004.

[17] R. L. Hanson, G. Imperatore, P. H. Bennett, and W. C. Knowler, "Components of the "metabolic syndrome" and incidence of type 2 diabetes," Diabetes, vol. 51, no. 10, pp. 3120-3127, 2002.

[18] H. E. Resnick, K. Jones, G. Ruotolo et al., "Insulin resistance, the metabolic syndrome, and risk of incident cardiovascular disease in nondiabetic American Indians: the Strong Heart Study," Diabetes Care, vol. 26, no. 3, pp. 861-867, 2003.

[19] B. E. K. Klein, R. Klein, and K. E. Lee, "Components of the metabolic syndrome and risk of cardiovascular disease and diabetes in Beaver Dam," Diabetes Care, vol. 25, no. 10, pp. 1790-1794, 2002.

[20] N. Sattar, A. Gaw, O. Scherbakova et al., "Metabolic syndrome with and without C-reactive protein as a predictor of coronary heart disease and diabetes in the West of Scotland Coronary Prevention Study," Circulation, vol. 108, no. 4, pp. 414-419, 2003.

[21] N. Sattar, A. McConnachie, A. G. Shaper et al., "Can metabolic syndrome usefully predict cardiovascular disease and diabetes? Outcome data from two prospective studies," Lancet, vol. 371, no. 9628, pp. 1927-1935, 2008.

[22] E. S. Ford, C. Li, and N. Sattar, "Metabolic syndrome and incident diabetes: current state of the evidence," Diabetes Care, vol. 31, no. 9, pp. 1898-1904, 2008.
[23] E. S. Ford, "Risks for all-cause mortality, cardiovascular disease, and diabetes associated with the metabolic syndrome: a summary of the evidence," Diabetes Care, vol. 28, no. 7, pp. 1769-1778, 2005.

[24] A. Galassi, K. Reynolds, and J. He, "Metabolic syndrome and risk of cardiovascular disease: a meta-analysis," American Journal of Medicine, vol. 119, no. 10, pp. 812-819, 2006.

[25] A. S. Gami, B. J. Witt, D. E. Howard et al., "Metabolic syndrome and risk of incident cardiovascular events and death. A systematic review and meta-analysis of longitudinal studies," Journal of the American College of Cardiology, vol. 49, no. 4, pp. 403-414, 2007.

[26] J. B. Meigs, P. W. F. Wilson, C. S. Fox et al., "Body mass index, metabolic syndrome, and risk of type 2 diabetes or cardiovascular disease," Journal of Clinical Endocrinology and Metabolism, vol. 91, no. 8, pp. 2906-2912, 2006.

[27] National Kidney Foundation, "K/DOQI clinical practice guidelines for chronic kidney disease: evaluation, classification, and stratification," American Journal of Kidney Diseases, vol. 39, pp. S1-S246, 2002.

[28] B. F. Culleton, M. G. Larson, P. W. F. Wilson, J. C. Evans, P. S. Parfrey, and D. Levy, "Cardiovascular disease and mortality in a community-based cohort with mild renal insufficiency," Kidney International, vol. 56, no. 6, pp. 2214-2219, 1999.

[29] R. N. Foley, P. S. Parfrey, and M. J. Sarnak, "Clinical epidemiology of cardiovascular disease in chronic renal disease," American Journal of Kidney Diseases, vol. 32, no. 5, pp. S112-S119, 1998.

[30] P. Muntner, J. He, L. Hamm, C. Loria, and P. K. Whelton, "Renal insufficiency and subsequent death resulting from cardiovascular disease in the United States," Journal of the American Society of Nephrology, vol. 13, no. 3, pp. 745-753, 2002.

[31] H. C. Gerstein, J. F. E. Mann, Q. Yi et al., "Albuminuria and risk of cardiovascular events, death, and heart failure in diabetic and nondiabetic individuals," Journal of the American Medical Association, vol. 286, no. 4, pp. 421-426, 2001.

[32] A. M. El Nahas and A. K. Bello, "Chronic kidney disease: the global challenge," Lancet, vol. 365, no. 9456, pp. 331-340, 2005.

[33] J. Coresh, B. C. Astor, T. Greene, G. Eknoyan, and A. S. Levey, "Prevalence of chronic kidney disease and decreased kidney function in the adult US population: Third National Health and Nutrition Examination Survey," American Journal of Kidney Diseases, vol. 41, no. 1, pp. 1-12, 2003.

[34] R. N. Foley, A. M. Murray, S. Li et al., "Chronic kidney disease and the risk for cardiovascular disease, renal replacement, and death in the United States medicare population, 1998 to 1999," Journal of the American Society of Nephrology, vol. 16, no. 2, pp. 489-495, 2005.

[35] J. F. E. Mann, H. C. Gerstein, J. Poque, J. Bosch, and S. Yusuf, "Renal insufficiency as a predictor of cardiovascular outcomes and the impact of ramipril: the HOPE randomized trial," Annals of Internal Medicine, vol. 134, no. 8, pp. 629636, 2001.

[36] A. S. Go, G. M. Chertow, D. Fan, C. E. McCulloch, and C. Y. Hsu, "Chronic kidney disease and the risks of death, cardiovascular events, and hospitalization," New England Journal of Medicine, vol. 351, no. 13, pp. 1296-1370, 2004.

[37] R. Vanholder, Z. Massy, A. Argiles et al., "Chronic kidney disease as cause of cardiovascular morbidity and mortality," Nephrology Dialysis Transplantation, vol. 20, pp. 1048-1056, 2005. 
[38] W. van Biesen, D. de Bacquer, F. Verbeke, J. Delanghe, N. Lameire, and R. Vanholder, "The glomerular filtration rate in an apparently healthy population and its relation with cardiovascular mortality during 10 years," European Heart Journal, vol. 28, no. 4, pp. 478-483, 2007.

[39] J. Fort, "Chronic renal failure: a cardiovascular risk factor," Kidney International, vol. 68, no. 99, pp. S25-S29, 2005.

[40] U.S. Renal Data System, "Atlas of end-stage renal disease in the United States," USRDS 2002 Annual Data Report, National Institutes of Health, National Institute of Diabetes and Digestive and Kidney Diseases, 2002, Bethesda, Md, USA, 2002.

[41] M. J. Sarnak, B. E. Coronado, T. Greene et al., "Cardiovascular disease risk factors in chronic renal insufficiency," Clinical Nephrology, vol. 57, no. 5, pp. 327-335, 2002.

[42] P. Muntner, J. Coresh, J. C. Smith, J. Eckfeldt, and M. J. Klag, "Plasma lipids and risk of developing renal dysfunction: the atherosclerosis risk in communities study," Kidney International, vol. 58, no. 1, pp. 293-301, 2000.

[43] J. Bergström, "Inflammation, malnutrition, cardiovascular disease and mortality in end-stage renal disease," Polskie Archiwum Medycyny Wewnetrznej, vol. 104, no. 4, pp. 641643, 2000.

[44] R. J. Middleton, P. S. Parfrey, and R. N. Foley, "Left ventricular hypertrophy in the renal patient," Journal of the American Society of Nephrology, vol. 12, no. 5, pp. 1079-1084, 2001.

[45] R. N. Foley, P. S. Parfrey, and M. J. Sarnak, "Epidemiology of cardiovascular disease in chronic renal disease," Journal of the American Society of Nephrology, vol. 9, no. 12, pp. S16-S23, 1998.

[46] R. N. Foley and P. S. Parfrey, "Cardiac disease in chronic uremia: clinical outcome and risk factors," Advances in Renal Replacement Therapy, vol. 4, no. 3, pp. 234-248, 1997.

[47] J. D. Harnett, R. N. Foley, G. M. Kent, P. E. Barre, D. Murray, and P. S. Parfrey, "Congestive heart failure in dialysis patients: prevalence, incidence, prognosis and risk factors," Kidney International, vol. 47, no. 3, pp. 884-890, 1995.

[48] P. S. Parfrey, R. N. Foley, J. D. Harnett, G. M. Kent, D. Murray, and P. E. Barre, "Outcome and risk factors of ischemic heart disease in chronic uremia," Kidney International, vol. 49, no. 5, pp. 1428-1434, 1996.

[49] D. L. Dries, D. V. Exner, M. J. Domanski, B. Greenberg, and L. W. Stevenson, "The prognostic implications of renal insufficiency in asymptomatic and symptomatic patients with left ventricular systolic dysfunction," Journal of the American College of Cardiology, vol. 35, no. 3, pp. 681-689, 2000.

[50] J. Al Suwaidi, D. N. Reddan, K. Williams et al., "Prognostic implications of abnormalities in renal function in patients with acute coronary syndromes," Circulation, vol. 106, no. 8, pp. 974-980, 2002.

[51] M. G. Shlipak, L. F. Fried, C. Crump et al., "Elevations of inflammatory and procoagulant biomarkers in elderly persons with renal insufficiency," Circulation, vol. 107, no. 1, pp. 87-92, 2003.

[52] P. Stenvinkel, O. Heimbürger, F. Paultre et al., "Strong association between malnutrition, inflammation, and atherosclerosis in chronic renal failure," Kidney International, vol. 55, no. 5, pp. 1899-1911, 1999.

[53] A. B. Irish, "Plasminogen activator inhibitor-1 activity in chronic renal disease and dialysis," Metabolism, vol. 46, no. 1, pp. 36-40, 1997.
[54] F. Kronenberg, "Homocysteine, lipoprotein(a) and fibrinogen: metabolic risk factors for cardiovascular complications of chronic renal disease," Current Opinion in Nephrology and Hypertension, vol. 7, no. 3, pp. 271-278, 1998.

[55] A. Festa, R. D’Agostino, G. Howard, L. Mykkänen, R. P. Tracy, and S. M. Haffner, "Chronic subclinical inflammation as part of the insulin resistance syndrome: the insulin resistance atherosclerosis study (IRAS)," Circulation, vol. 102, no. 1, pp. 42-47, 2000.

[56] J. C. Pickup, M. B. Mattock, G. D. Chusney, and D. Burt, "NIDDM as a disease of the innate immune system: association of acute- phase reactants and interleukin-6 with metabolic syndrome X," Diabetologia, vol. 40, no. 11, pp. 1286-1292, 1997.

[57] V. Panichi, M. Migliori, S. de Pietro et al., "C-reactive protein as a marker of chronic inflammation in uremic patients," Blood Purification, vol. 18, no. 3, pp. 183-190, 2000.

[58] L. Mykkänen, D. J. Zaccaro, D. H. O’Leary, G. Howard, D. C. Robbins, and S. M. Haffner, "Microalbuminuria and carotid artery intima-media thickness in nondiabetic and NIDDM subjects: the insulin resistance atheroselerosis study (IRAS)," Stroke, vol. 28, no. 9, pp. 1710-1716, 1997.

[59] W. G. Goodman, J. Goldin, B. D. Kuizon et al., "Coronaryartery calcification in young adults with end-stage renal disease who are undergoing dialysis," New England Journal of Medicine, vol. 342, no. 20, pp. 1478-1483, 2000.

[60] R. Zatz, B. R. Dunn, and T. W. Meyer, "Prevention of diabetic glomerulopathy by pharmacological amelioration of glomerular capillary hypertension," Journal of Clinical Investigation, vol. 77, no. 6, pp. 1925-1930, 1986.

[61] M. E. Cooper, "Pathogenesis, prevention, and treatment of diabetic nephropathy," Lancet, vol. 352, no. 9123, pp. 213219, 1998.

[62] P. K. Whelton, T. V. Perneger, J. He, and M. J. Klag, “The role of blood pressure as a risk factor for renal disease: a review of the epidemiologic evidence," Journal of Human Hypertension, vol. 10, no. 10, pp. 683-689, 1996.

[63] K. Iseki, Y. Ikemiya, K. Kinjo, T. Inoue, C. Iseki, and S. Takishita, "Body mass index and the risk of development of end-stage renal disease in a screened cohort," Kidney International, vol. 65, no. 5, pp. 1870-1876, 2004.

[64] J. D. Kopple, T. Greene, W. C. Chumlea et al., "Relationship between nutritional status and the glomerular filtration rate: results from the MDRD study," Kidney International, vol. 57, no. 4, pp. 1688-1703, 2000.

[65] M. Manttari, E. Tiula, T. Alikoski, and V. Manninen, "Effects of hypertension and dyslipidemia on the decline in renal function," Hypertension, vol. 26, no. 4, pp. 670-675, 1995.

[66] L. G. Hunsicker, S. Adler, A. Caggiula et al., "Predictors of the progression of renal disease in the Modification of Diet in Renal Disease Study," Kidney International, vol. 51, no. 6, pp. 1908-1919, 1997.

[67] L. F. Fried, T. J. Orchard, and B. L. Kasiske, "Effect of lipid reduction on the progression of renal disease: a metaanalysis," Kidney International, vol. 59, no. 1, pp. 260-269, 2001.

[68] J. Chen, P. Muntner, L. L. Hamm et al., "The metabolic syndrome and chronic kidney disease in U.S. Adults," Annals of Internal Medicine, vol. 140, no. 3, pp. 167-I39, 2004.

[69] L. Mykkänen, D. J. Zaccaro, L. E. Wagenknecht, D. C. Robbins, M. Gabriel, and S. M. Haffner, "Microalbuminuria is associated with insulin resistance in nondiabetic subjects: the insulin resistance atherosclerosis study," Diabetes, vol. 47, no. 5, pp. 793-800, 1998. 
[70] C. M. Hoehner, K. J. Greenlund, S. Rith-Najarian, M. L. Casper, and W. M. McClellan, "Association of the insulin resistance syndrome and microalbuminuria among nondiabetic native Americans. The Inter-Tribal Heart Project," Journal of the American Society of Nephrology, vol. 13, no. 6, pp. 1626-1634, 2002.

[71] L. Palaniappan, M. Carnethon, and S. P. Fortmann, "Association between microalbuminuria and the metabolic syndrome: NHANES III," American Journal of Hypertension, vol. 16, no. 11, pp. 952-958, 2003.

[72] R. Fujikawa, M. Okubo, G. Egusa, and N. Kohno, "Insulin resistance precedes the appearance of albuminuria in nondiabetic subjects: 6 years follow up study," Diabetes Research and Clinical Practice, vol. 53, no. 2, pp. 99-106, 2001.

[73] L. Zhang, L. Zuo, F. Wang et al., "Metabolic syndrome and chronic kidney disease in a Chinese population aged 40 years and older," Mayo Clinic Proceedings, vol. 82, no. 7, pp. 822827, 2007.

[74] M. Kurella, J. C. Lo, and G. M. Chertow, "Metabolic syndrome and the risk for chronic kidney disease among nondiabetic adults," Journal of the American Society of Nephrology, vol. 16, no. 7, pp. 2134-2140, 2005.

[75] H. Tanaka, Y. Shiohira, Y. Uezu, A. Higa, and K. Iseki, "Metabolic syndrome and chronic kidney disease in Okinawa, Japan," Kidney International, vol. 69, no. 2, pp. 369374, 2006

[76] A. Rashidi, A. Ghanbarian, and F. Azizi, "Are patients who have metabolic syndrome without diabetes at risk for developing chronic kidney disease? Evidence based on data from a large cohort screening population," Clinical Journal of the American Society of Nephrology, vol. 2, no. 5, pp. 976-983, 2007.

[77] J. Chen, D. Gu, C. S. Chen et al., "Association between the metabolic syndrome and chronic kidney disease in Chinese adults," Nephrology Dialysis Transplantation, vol. 22, no. 4, pp. 1100-1106, 2007.

[78] C. Kitiyakara, S. Yamwong, S. Cheepudomwit et al., "The metabolic syndrome and chronic kidney disease in a Southeast Asian cohort," Kidney International, vol. 71, no. 7, pp. 693-700, 2007.

[79] A. O. Y. Luk, W. Y. So, R. C. W. Ma et al., "Metabolic syndrome predicts new onset of chronic kidney disease in 5,829 patients with type 2 diabetes A 5-year prospective analysis of the Hong Kong diabetes registry," Diabetes Care, vol. 31, no. 12, pp. 2357-2361, 2008.

[80] S. Y. Jang, I.-H. Kim, E. Y. Ju, S. J. Ahn, D.-K. Kim, and S. W. Lee, "Chronic kidney disease and metabolic syndrome in a general Korean population: the Third Korea National Health and Nutrition Examination Survey (KNHANES III) Study," Journal of Public Health, vol. 32, no. 4, pp. 538-546, 2010.

[81] M. Yu, D. R. Ryu, S. J. Kim, K. B. Choi, and D. H. Kang, "Clinical implication of metabolic syndrome on chronic kidney disease depends on gender and menopausal status: results from the Korean National Health and Nutrition Examination Survey," Nephrology Dialysis Transplantation, vol. 25, no. 2, pp. 469-477, 2010.

[82] B. Becker, F. Kronenberg, J. T. Kielstein et al., "Renal insulin resistance syndrome, adiponectin and cardiovascular events in patients with kidney disease: the mild and moderate kidney disease study," Journal of the American Society of Nephrology, vol. 16, no. 4, pp. 1091-1098, 2005.

[83] L. M. Thorn, C. Forsblom, J. Fagerudd et al., "Metabolic syndrome in type 1 diabetes: association with diabetic nephropathy and glycemic control (the FinnDiane study)," Diabetes Care, vol. 28, no. 8, pp. 2019-2024, 2005.

[84] S. Kobayashi, S. Maejima, T. Ikeda, and M. Nagase, "Impact of dialysis therapy on insulin resistance in end-stage renal disease: comparison of haemodialysis and continuous ambulatory peritoneal dialysis," Nephrology Dialysis Transplantation, vol. 15, no. 1, pp. 65-70, 2000.

[85] S. J. L. Bakker, R. T. Gansevoort, and D. de Zeeuw, "Metabolic syndrome: a fata morgana?" Nephrology Dialysis Transplantation, vol. 22, no. 1, pp. 15-20, 2007.

[86] J. Chen, P. Muntner, L. L. Hamm et al., "Insulin resistance and risk of chronic kidney disease in nondiabetic US adults," Journal of the American Society of Nephrology, vol. 14, no. 2, pp. 469-477, 2003.

[87] C. Y. Hsu, C. E. McCulloch, C. Iribarren, J. Darbinian, and A. S. Go, "Body mass index and risk for end-stage renal disease," Annals of Internal Medicine, vol. 144, no. 1, pp. 21-28, 2006.

[88] A. Sjoholm and T. Nystrom, "Endothelial inflammation in insulin resistance," Lancet, vol. 365, no. 9459, pp. 610-612, 2005.

[89] J. R. Sowers, "Metabolic risk factors and renal disease," Kidney International, vol. 71, no. 8, pp. 719-720, 2007.

[90] U. Özcan, Q. Cao, E. Yilmaz et al., "Endoplasmic reticulum stress links obesity, insulin action, and type 2 diabetes," Science, vol. 306, no. 5695, pp. 457-461, 2004.

[91] H. Kaneto, Y. Nakatani, T. Miyatsuka et al., "Possible novel therapy for diabetes with cell-permeable JNK-inhibitory peptide," Nature Medicine, vol. 10, no. 10, pp. 1128-1132, 2004.

[92] D. J. Bridgewater, J. Ho, V. Sauro, and D. G. Matsell, "Insulinlike growth factors inhibit podocyte apoptosis through the PI3 kinase pathway," Kidney International, vol. 67, no. 4, pp. 1308-1314, 2005.

[93] M. Carlyle, O. B. Jones, J. J. Kuo, and J. E. Hall, “Chronic cardiovascular and renal actions of leptin: role of adrenergic activity," Hypertension, vol. 39, no. 2, pp. 496-501, 2002.

[94] V. Moreno-Manzano, Y. Ishikawa, J. Lucio-Cazana, and M. Kitamura, "Selective involvement of superoxide anion, but not downstream compounds hydrogen peroxide and peroxynitrite, in tumor necrosis factor- $\alpha$-induced apoptosis of rat mesangial cells," Journal of Biological Chemistry, vol. 275, no. 17, pp. 12684-12691, 2000.

[95] X. Zhou, G. Yang, C. A. Davis et al., "Hydrogen peroxide mediates FK506-induced cytotoxicity in renal cells," Kidney International, vol. 65, no. 1, pp. 139-147, 2004.

[96] T. S. Perlstein, M. Gerhard-Herman, N. K. Hollenberg, G. $\mathrm{H}$. Williams, and A. Thomas, "Insulin induces renal vasodilation, increases plasma renin activity, and sensitizes the renal vasculature to angiotensin receptor blockade in healthy subjects," Journal of the American Society of Nephrology, vol. 18, no. 3, pp. 944-951, 2007.

[97] B. Balkau and M. A. Charles, "Comment on the provisional report from the WHO consultation," Diabetic Medicine, vol. 16, no. 5, pp. 442-443, 1999.

[98] M. Khamaisi, A. Flyvbjerg, Z. Haramati, G. Raz, I. D. Wexler, and I. Raz, "Effect of mild hypoinsulinemia on renal hypertrophy: growth hormone/insulin-like growth factor 1 system in mild streptozotocin diabetes," International Journal of Experimental Diabetes Research, vol. 3, no. 4, pp. 257-264, 2002.

[99] S. Wang, M. DeNichilo, C. Brubaker, and R. Hirschberg, "Connective tissue growth factor in tubulointerstitial injury of diabetic nephropathy," Kidney International, vol. 60, no. 1, pp. 96-105, 2001. 
[100] E. Lupia, S. J. Elliot, O. Lenz et al., "IGF-1 decreases collagen degradation in diabetic NOD mesangial cells: implications for diabetic nephropathy," Diabetes, vol. 48, no. 8, pp. 1638 1644, 1999.

[101] N. Kambham, G. S. Markowitz, A. M. Valeri, J. Lin, and V. D. D’Agati, "Obesity-related glomerulopathy: an emerging epidemic," Kidney International, vol. 59, no. 4, pp. 14981509, 2001.

[102] A. H. Cohen, "Massive obesity and the kidney: a morphologic and statistical study," American Journal of Pathology, vol. 81, no. 1, pp. 117-127, 1975.

[103] B. L. Kasiske, M. P. O’Donnell, and W. F. Keane, “The Zucker rat model of obesity, insulin resistance, hyperlipidemia, and renal injury," Hypertension, vol. 19, no. 1, pp. I110-I115, 1992.

[104] A. Chagnac, T. Weinstein, A. Korzets, E. Ramadan, J. Hirsch, and U. Gafter, "Glomerular hemodynamics in severe obesity," American Journal of Physiology—Renal Physiology, vol. 278, no. 5, pp. F817-F822, 2000.

[105] A. Chagnac, T. Weinstein, M. Herman, J. Hirsh, U. Gafter, and Y. Ori, "The effects of weight loss on renal function in patients with severe obesity," Journal of the American Society of Nephrology, vol. 14, no. 6, pp. 1480-1486, 2003.

[106] M. Tomaszewski, F. J. Charchar, C. Maric et al., "Glomerular hyperfiltration: a new marker of metabolic risk," Kidney International, vol. 71, no. 8, pp. 816-821, 2007.

[107] K. R. Tuttle, J. L. Bruton, M. C. Perusek, J. L. Lancaster, D. T. Kopp, and R. A. DeFronzo, "Effect of strict glycemic control on renal hemodynamic response to amino acids and renal enlargement in insulin-dependent diabetes mellitus," New England Journal of Medicine, vol. 324, no. 23, pp. 1626-1632, 1991.

[108] K. R. Tuttle, M. E. Puhlman, S. K. Cooney, and R. A. Short, "Effects of amino acids and glucagon on renal hemodynamics in type 1 diabetes," American Journal of Physiology—Renal Physiology, vol. 282, no. 1, pp. F103-F112, 2002.

[109] D. A. Maddox, F. K. Alavi, R. N. Santella, and E. T. Zawada Jr., "Prevention of obesity-linked renal disease: age-dependent effects of dietary food restriction," Kidney International, vol. 62, no. 1, pp. 208-219, 2002.

[110] R. L. Meek, S. K. Cooney, S. D. Flynn et al., "Amino acids induce indicators of response to injury in glomerular mesangial cells," American Journal of Physiology — Renal Physiology, vol. 285, no. 1, pp. F79-F86, 2003.

[111] K. R. Tuttle, E. C. Johnson, S. K. Cooney et al., "Amino acids injure mesangial cells by advanced glycation end products, oxidative stress, and protein kinase C," Kidney International, vol. 67, no. 3, pp. 953-968, 2005.

[112] D. Bonnefont-Rousselot, J. P. Bastard, M. C. Jaudon, and J. Delattre, "Consequences of the diabetic status on the oxidant/antioxidant balance," Diabetes and Metabolism, vol. 26, no. 3, pp. 163-176, 2000.

[113] B. P. Oberg, E. McMenamin, F. L. Lucas et al., "Increased prevalence of oxidant stress and inflammation in patients with moderate to severe chronic kidney disease," Kidney International, vol. 65, no. 3, pp. 1009-1016, 2004.

[114] T. Nishikawa and E. Araki, "Impact of mitochondrial ROS production in the pathogenesis of diabetes mellitus and its complications," Antioxidants and Redox Signaling, vol. 9, no. 3, pp. 343-353, 2007.
[115] X. Z. Ruan, Z. Varghese, S. H. Powis, and J. F. Moorhead, "Human mesangial cells express inducible macrophage scavenger receptor," Kidney International, vol. 56, no. 2, pp. 440451, 1999.

[116] X. Z. Ruan, Z. Varghese, and J. F. Moorhead, "Inflammation modifies lipid-mediated renal injury," Nephrology Dialysis Transplantation, vol. 18, no. 1, pp. 27-32, 2003.

[117] I. Gavras and H. Gavras, "Angiotensin II as a cardiovascular risk factor," Journal of Human Hypertension, vol. 16, no. 2, pp. S2-S6, 2002.

[118] L. Chalmers, F. J. Kaskel, and O. Bamgbola, "The role of obesity and its bioclinical correlates in the progression of chronic kidney disease," Advances in Chronic Kidney Disease, vol. 13, no. 4, pp. 352-364, 2006.

[119] C. Guichard, R. Moreau, D. Pessayre, T. K. Epperson, and K. H. Krause, "NOX family NADPH oxidases in liver and in pancreatic islets: a role in the metabolic syndrome and diabetes?" Biochemical Society Transactions, vol. 36, no. 5, pp. 920-929, 2008.

[120] S. S. Prabhakar, "Role of nitric oxide in diabetic nephropathy," Seminars in Nephrology, vol. 24, no. 4, pp. 333-344, 2004.

[121] G. L. Bakris, "Clinical importance of microalbuminuria in diabetes and hypertension," Current Hypertension Reports, vol. 6, no. 5, pp. 352-356, 2004.

[122] J. P. Garg and G. L. Bakris, "Microalbuminuria: marker of vascular dysfunction, risk factor for cardiovascular disease," Vascular Medicine, vol. 7, no. 1, pp. 35-43, 2002.

[123] M. Montagnani, L. V. Ravichandran, H. Chen, D. L. Esposito, and M. J. Quon, "Insulin receptor substrate-1 and phosphoinositide-dependent kinase-1 are required for insulin-stimulated production of nitric oxide in endothelial cells," Molecular Endocrinology, vol. 16, no. 8, pp. 1931-1942, 2002.

[124] H. Chen, M. Montagnani, T. Funahashi, I. Shimomura, and M. J. Quon, "Adiponectin stimulates production of nitric oxide in vascular endothelial cells," Journal of Biological Chemistry, vol. 278, no. 45, pp. 45021-45026, 2003.

[125] H. Laine, M. J. Knuuti, U. Ruotsalainen et al., "Insulin resistance in essential hypertension is characterized by impaired insulin stimulation of blood flow in skeletal muscle," Journal of Hypertension, vol. 16, no. 2, pp. 211-219, 1998.

[126] H. O. Steinberg, H. Chaker, R. Leaming, A. Johnson, G. Brechtel, and A. D. Baron, "Obesity/insulin resistance is associated with endothelial dysfunction: implications for the syndrome of insulin resistance," Journal of Clinical Investigation, vol. 97, no. 11, pp. 2601-2610, 1996.

[127] H. O. Steinberg, G. Paradisi, G. Hook, K. Crowder, J. Cronin, and A. D. Baron, "Free fatty acid elevation impairs insulin-mediated vasodilation and nitric oxide production," Diabetes, vol. 49, no. 7, pp. 1231-1238, 2000.

[128] G. Anfossi, F. Cavalot, P. Massucco et al., "Insulin influences immunoreactive endothelin release by human vascular smooth muscle cells," Metabolism, vol. 42, no. 9, pp. 10811083, 1993.

[129] C. Ferri, V. Pittoni, A. Piccoli et al., "Insulin stimulates endothelin-1 secretion from human endothelial cells and modulates its circulating levels in vivo," Journal of Clinical Endocrinology and Metabolism, vol. 80, no. 3, pp. 829-835, 1995.

[130] T. A. Marsen, H. Schramek, and M. J. Dunn, "Renal actions of endothelin: linking cellular signaling pathways to kidney 
disease," Kidney International, vol. 45, no. 2, pp. 336-344, 1994.

[131] P. Cirillo, Y. Y. Sautin, J. Kanellis et al., "Systemic inflammation, metabolic syndrome and progressive renal disease," Nephrology Dialysis Transplantation, vol. 24, no. 5, pp. 13841387, 2009.

[132] A. R. Gaby, "Adverse effects of dietary fructose," Alternative Medicine Review, vol. 10, no. 4, pp. 294-306, 2005.

[133] S. S. Elliott, N. L. Keim, J. S. Stern, K. Teff, and P. J. Havel, "Fructose, weight gain, and the insulin resistance syndrome," American Journal of Clinical Nutrition, vol. 76, no. 5, pp. 911922, 2002.

[134] I. Hwang, H. Ho, B. B. Hoffman, and G. M. Reaven, "Fructose-induced insulin resistance and hypertension in rats," Hypertension, vol. 10, no. 5, pp. 512-516, 1987.

[135] J. T. Dwyer, M. Evans, E. J. Stone et al., "Adolescents' eating patterns influence their nutrient intakes," Journal of the American Dietetic Association, vol. 101, no. 7, pp. 798-802, 2001.

[136] D. B. Corry, P. Eslami, K. Yamamoto, M. D. Nyby, H. Makino, and M. L. Tuck, "Uric acid stimulates vascular smooth muscle cell proliferation and oxidative stress via the vascular renin-angiotensin system," Journal of Hypertension, vol. 26, no. 2, pp. 269-275, 2008.

[137] R. Cirillo, M. S. Gersch, W. Mu et al., "Ketohexokinasedependent metabolism of fructose Induces proinflammatory mediators in proximal tubular cells," Journal of the American Society of Nephrology, vol. 20, no. 3, pp. 545-553, 2009.

[138] C. A. Roncal, W. Mu, B. Croker et al., "Effect of elevated serum uric acid on cisplatin-induced acute renal failure," American Journal of Physiology—Renal Physiology, vol. 292, no. 1, pp. F116-F122, 2007.

[139] D. H. Kang, T. Nakagawa, L. Feng et al., "A role for uric acid in the progression of renal disease," Journal of the American Society of Nephrology, vol. 13, no. 12, pp. 2888-2897, 2002.

[140] P. M. Ridker, C. H. Hennekens, J. E. Buring, and N. Rifai, "Creactive protein and other markers of inflammation in the prediction of cardiovascular disease in women," New England Journal of Medicine, vol. 342, no. 12, pp. 836-843, 2000.

[141] S. Soriano, L. González, A. Martín-Malo, M. Rodríguez, P. Aljama, and S. S. Cabrera, "C-reactive protein and low albumin are predictors of morbidity and cardiovascular events in chronic kidney disease (CKD) 3-5 patients," Clinical Nephrology, vol. 67, no. 6, pp. 352-357, 2007.

[142] M. Arici and J. Walls, "End-stage renal disease, atherosclerosis, and cardiovascular mortality: is C-reactive protein the missing link?" Kidney International, vol. 59, no. 2, pp. 407414, 2001.

[143] M. Bochud, J. Nussberger, P. Bovet et al., "Plasma aldosterone is independently associated with the metabolic syndrome," Hypertension, vol. 48, no. 2, pp. 239-245, 2006.

[144] S. Kidambi, J. M. Kotchen, C. E. Grim et al., "Association of adrenal steroids with hypertension and the metabolic syndrome in blacks," Hypertension, vol. 49, no. 3, pp. 704$711,2007$.

[145] G. Colussi, C. Catena, R. Lapenna, E. Nadalini, A. Chiuch, and L. A. Sechi, "Insulin resistance and hyperinsulinemia are related to plasma aldosterone levels in hypertensive patients," Diabetes Care, vol. 30, no. 9, pp. 2349-2354, 2007.

[146] T. Fujita, "Spotlight on renin. The renin system, saltsensitivity and metabolic syndrome," Journal of the ReninAngiotensin-Aldosterone System, vol. 7, no. 3, pp. 181-183, 2006.
[147] P. Korantzopoulos, M. Elisaf, and H. J. Milionis, "Multifactorial intervention in metabolic syndrome targeting at prevention of chronic kidney disease-ready for prime time?" Nephrology Dialysis Transplantation, vol. 22, no. 10, pp. 2768-2774, 2007.

[148] P. Gæde, P. Vedel, N. Larsen, G. V. H. Jensen, H. H. Parving, and O. Pedersen, "Multifactorial intervention and cardiovascular disease in patients with type 2 diabetes," New England Journal of Medicine, vol. 348, no. 5, pp. 383-393, 2003.

[149] R. W. Schrier, R. O. Estacio, A. Esler, and P. Mehler, "Effects of aggressive blood pressure control in normotensive type 2 diabetic patients on albuminuria, retinopathy and strokes," Kidney International, vol. 61, no. 3, pp. 1086-1097, 2002.

[150] A. Patel, S. MacMahon, J. Chalmers et al., "Intensive blood glucose control and vascular outcomes in patients with type 2 diabetes," New England Journal of Medicine, vol. 358, no. 24, pp. 2560-2572, 2008.

[151] H. C. Gerstein, M. E. Miller, R. P. Byington et al., "Effects of intensive glucose lowering in type 2 diabetes," New England Journal of Medicine, vol. 358, no. 24, pp. 2545-2559, 2008.

[152] W. C. Cushman, G. W. Evans, R. P. Byington et al., "Effects of intensive blood-pressure control in type 2 diabetes mellitus," New England Journal of Medicine, vol. 362, no. 17, pp. 15751585, 2010.

[153] I. Eidemak, B. Feldt-Rasmussen, I. L. Kanstrup, S. L. Nielsen, O. Schmitz, and S. Strandgaard, "Insulin resistance and hyperinsulinaemia in mild to moderate progressive chronic renal failure and its association with aerobic work capacity," Diabetologia, vol. 38, no. 5, pp. 565-572, 1995.

[154] R. R. Wing and B. Marquez, "Behavioral aspects of weight loss in type 2 diabetes," Current Diabetes Reports, vol. 8 , no. 2, pp. 126-131, 2008.

[155] M. Navarro-Díaz, A. Serra, R. Romero et al., "Effect of drastic weight loss after bariatric surgery on renal parameters in extremely obese patients: long-term follow-up," Journal of the American Society of Nephrology, vol. 17, supplement 3, pp. S213-S217, 2006.

[156] S. B. Heymsfield, K. R. Segal, J. Hauptman et al., "Effects of weight loss with orlistat on glucose tolerance and progression to type 2 diabetes in obese adults," Archives of Internal Medicine, vol. 160, no. 9, pp. 1321-1326, 2000.

[157] K. Esposito, R. Marfella, M. Ciotola et al., "Effect of a Mediterranean-style diet on endothelial dysfunction and markers of vascular inflammation in the metabolic syndrome: a randomized trial," Journal of the American Medical Association, vol. 292, no. 12, pp. 1440-1446, 2004.

[158] American Diabetes Association, "Standards of medical care in diabetes 2010," Diabetes Care, vol. 33, supplement 1, pp. S11-S61, 2010.

[159] J. P. Casas, W. Chua, S. Loukogeorgakis et al., "Effect of inhibitors of the renin-angiotensin system and other antihypertensive drugs on renal outcomes: systematic review and meta-analysis," Lancet, vol. 366, no. 9502, pp. 2026-2033, 2005.

[160] R. E. Schmieder, K. F. Hilgers, M. P. Schlaich, and B. M. Schmidt, "Renin-angiotensin system and cardiovascular risk," Lancet, vol. 369, no. 9568, pp. 1208-1219, 2007.

[161] R. H. Eckel, S. M. Grundy, and P. Z. Zimmet, "The metabolic syndrome," Lancet, vol. 365, no. 9468, pp. 1415-1428, 2005.

[162] G. Mancia, G. de Backer, A. Dominiczak et al., "2007 Guidelines for the Management of Arterial Hypertension: The Task Force for the Management of Arterial Hypertension of the European Society of Hypertension (ESH) and of 
the European Society of Cardiology (ESC)," Journal of Hypertension, vol. 25, no. 6, pp. 1105-1187, 2007.

[163] T. H. Jafar, P. C. Stark, C. H. Schmid et al., "Progression of chronic kidney disease: the role of blood pressure control, proteinuria, and angiotensin-converting enzyme inhibition: a patient-level meta-analysis," Annals of Internal Medicine, vol. 139, no. 4, pp. 244-252, 2003.

[164] T. J. Orchard, M. Temprosa, R. Goldberg et al., "The effect of metformin and intensive lifestyle intervention on the metabolic syndrome: the diabetes prevention program randomized trial," Annals of Internal Medicine, vol. 142, no. 8, pp. 611-619, 2005.

[165] W. C. Knowler, E. Barrett-Connor, S. E. Fowler et al., "Reduction in the incidence of type 2 diabetes with lifestyle intervention or metformin," New England Journal of Medicine, vol. 346, no. 6, pp. 393-403, 2002.

[166] S. Giannini, M. Serio, and A. Galli, "Pleiotropic effects of thiazolidinediones: taking a look beyond antidiabetic activity," Journal of Endocrinological Investigation, vol. 27, no. 10, pp. 982-991, 2004.

[167] H. C. Gerstein, S. Yusuf, J. Bosch et al., "Effect of rosiglitazone on the frequency of diabetes in patients with impaired glucose tolerance or impaired fasting glucose: a randomised controlled trial," Lancet, vol. 368, pp. 1096-1105, 2006.

[168] S. E. Nissen and K. Wolski, "Effect of rosiglitazone on the risk of myocardial infarction and death from cardiovascular causes," New England Journal of Medicine, vol. 356, no. 24, pp. 2457-2471, 2007.

[169] L. R. Kurukulasuriya and J. R. Sowers, “Therapies for type 2 diabetes: lowering $\mathrm{HbAlc}$ and associated cardiovascular risk factors," Cardiovascular Diabetology, vol. 9, article 45, 2010.

[170] F. A. van de Laar, P. L. B. J. Lucassen, R. P. Akkermans, E. H. van de Lisdonk, and W. J. C. de Grauw, "Alpha-glucosidase inhibitors for people with impaired glucose tolerance or impaired fasting blood glucose," Cochrane Database of Systematic Reviews, no. 4, Article ID CD005061, 2006.

[171] M. Hanefeld, J. L. Chiasson, C. Koehler, E. Henkel, F. Schaper, and T. Temelkova-Kurktschiev, "Acarbose slows progression of intima-media thickness of the carotid arteries in subjects with impaired glucose tolerance," Stroke, vol. 35, no. 5, pp. 1073-1078, 2004.

[172] J.-L. Chiasson, R. G. Josse, R. Gomis, M. Hanefeld, A. Karasik, and M. Laakso, "Acarbose treatment and the risk of cardiovascular disease and hypertension in patients with impaired glucose tolerance: the STOP-NIDDM trial," Journal of the American Medical Association, vol. 290, no. 4, pp. 486494, 2003.

[173] R. E. Amori, J. Lau, and A. G. Pittas, "Efficacy and safety of incretin therapy in type 2 diabetes: systematic review and meta-analysis," Journal of the American Medical Association, vol. 298, no. 2, pp. 194-206, 2007.

[174] R. Bhushan, K. E. Elkind-Hirsch, M. Bhushan, W. J. Butler, K. Duncan, and O. Marrioneaux, "Exenatide use in the management of metabolic syndrome: a retrospective data base study," Endocrine Practice, vol. 14, no. 8, pp. 933-999, 2008.

[175] R. Bergenstal, T. Kim, M. Trautmann, D. Zhuang, T. Okerson, and K. Taylor, "Exenatide once weekly elicited improvements in blood pressure and lipid profile over 52 weeks in patients with type 2 diabetes," Circulation, vol. 118, p. S1086, 2008.

[176] G. C. Mistry, A. L. Maes, K. C. Lasseter et al., "Effect of sitagliptin, a dipeptidyl peptidase- 4 inhibitor, on blood pressure in nondiabetic patients with mild to moderate hypertension," Journal of Clinical Pharmacology, vol. 48, no. 5, pp. 592-598, 2008.

[177] G. Derosa, P. Maffioli, S. A. T. Salvadeo et al., "Exenatide versus glibenclamide in patients with diabetes," Diabetes Technology and Therapeutics, vol. 12, no. 3, pp. 233-240, 2010.

[178] D. M. Nathan, J. B. Buse, M. B. Davidson et al., "Medical management of hyperglycemia in type 2 diabetes: a consensus algorithm for the initiation and adjustment of therapya consensus statement of the American Diabetes Association and the European Association for the Study of Diabetes," Clinical Diabetes, vol. 32, no. 1, pp. 193-203, 2009.

[179] UK Prospective Diabetes Study (UKPDS) Group, "Intensive blood-glucose control with sulphonylureas or insulin compared with conventional treatment and risk of complications in patients with type 2 diabetes (UKPDS 33)," Lancet, vol. 12, no. 352, pp. 837-353, 1998.

[180] K. Pyörälä, C. M. Ballantyne, B. Gumbiner et al., "Reduction of cardiovascular events by simvastatin in nondiabetic coronary heart disease patients with and without the metabolic syndrome: subgroup analyses of the Scandinavian Simvastatin Survival Study (4S)," Diabetes Care, vol. 27, no. 7, pp. 1735-1740, 2004.

[181] P. Deedwania, P. Barter, R. Carmena et al., "Reduction of low-density lipoprotein cholesterol in patients with coronary heart disease and metabolic syndrome: analysis of the Treating to New Targets study," Lancet, vol. 368, no. 9539, pp. 919-928, 2006.

[182] S. Sandhu, N. Wiebe, L. F. Fried, and M. Tonelli, "Statins for improving renal outcomes: a meta-Analysis," Journal of the American Society of Nephrology, vol. 17, no. 7, pp. 2006-2016, 2006.

[183] K. Douglas, P. G. O’Malley, and J. L. Jackson, "Meta-analysis: the effect of statins on albuminuria," Annals of Internal Medicine, vol. 145, no. 2, pp. 117-124, 2006.

[184] V. G. Athyros, D. P. Mikhailidis, E. N. Liberopoulos et al., "Effect of statin treatment on renal function and serum uric acid levels and their relation to vascular events in patients with coronary heart disease and metabolic syndrome," Nephrology Dialysis Transplantation, vol. 22, no. 1, pp. 118127, 2007.

[185] J.-C. Ansquer, C. Foucher, S. Rattier, M.-R. Taskinen, and G. Steiner, "Fenofibrate reduces progression to microalbuminuria over 3 years in a placebo-controlled study in type 2 diabetes: results from the Diabetes Atherosclerosis Intervention Study (DAIS)," American Journal of Kidney Diseases, vol. 45, no. 3, pp. 485-493, 2005.

[186] R. Kahn, J. Buse, E. Ferrannini, and M. Stern, "The metabolic syndrome: time for a critical appraisal-joint statement from the American Diabetes Association and the European Association for the Study of Diabetes," Diabetes Care, vol. 28, no. 9, pp. 2289-2304, 2005.

[187] M. P. Stern, K. Williams, C. González-Villalpando, K. J. Hunt, and S. M. Haffner, "Does the metabolic-syndrome improve identification of individuals at risk of type 2 diabetes and/or cardiovascular disease?" Diabetes Care, vol. 27, no. 11, pp. 2676-2681, 2004. 


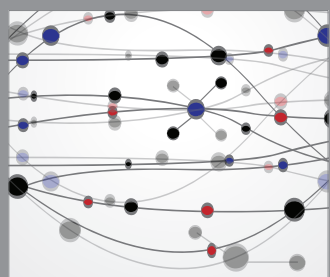

The Scientific World Journal
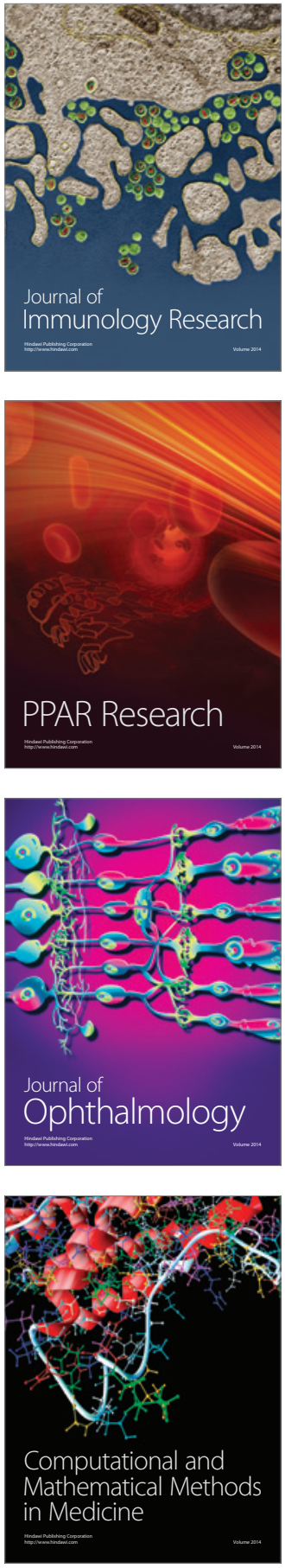

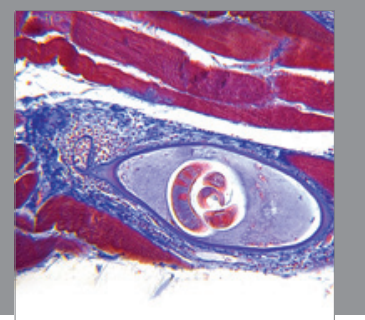

Gastroenterology

Research and Practice
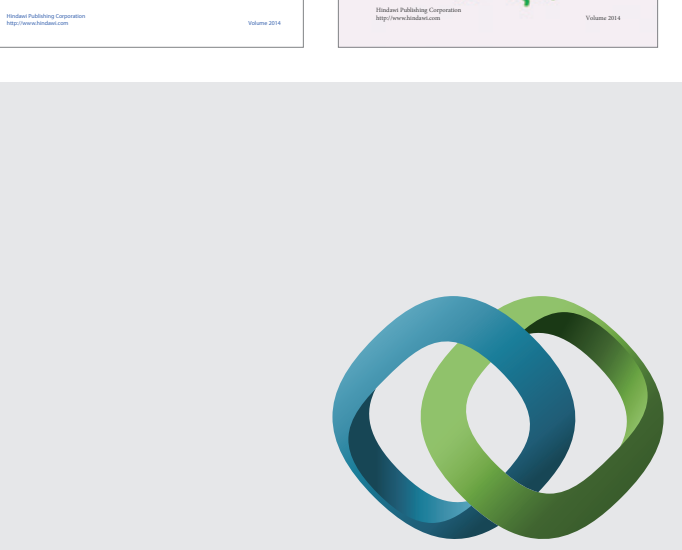

\section{Hindawi}

Submit your manuscripts at

http://www.hindawi.com
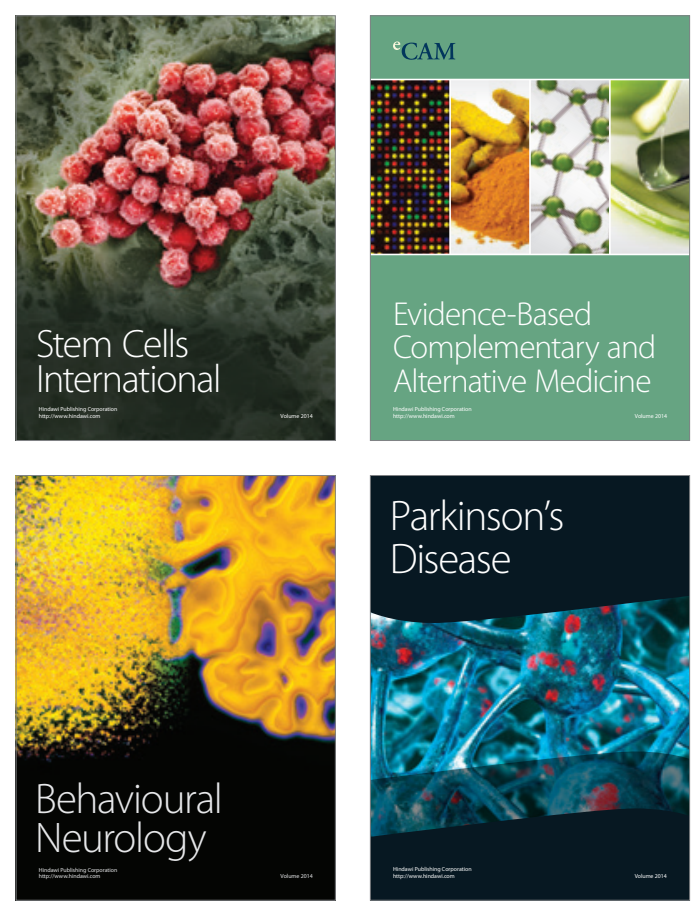

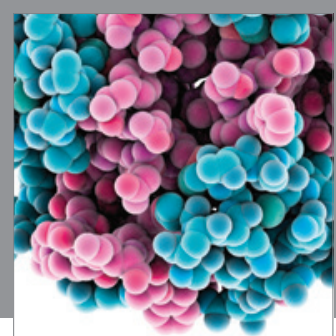

Journal of
Diabetes Research

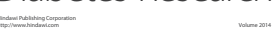

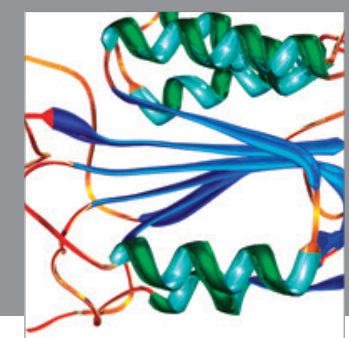

Disease Markers
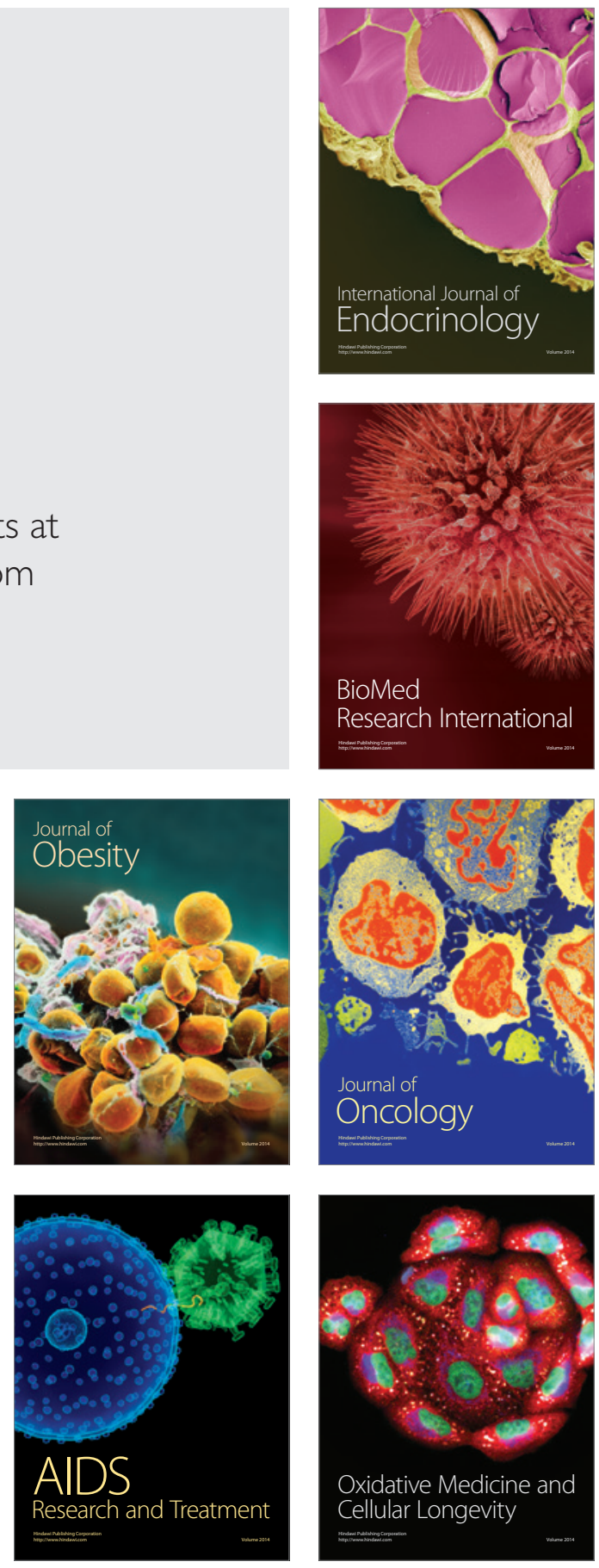